\title{
Geri Kabul Anlaşması ve Vizesiz Avrupa: Türkiye’nin Dış Politika Tercihlerini Anlamak
}

Melike AKKARACA KÖSE*

Öz

Bu makale, Türkiye’nin AB Göç Politikalarına uyum konusundaki dış politika tercihlerini anlamayı amaçlamaktadır. Avrupalılaşma modelleri ile yapılan fayda-maliyet analizleri kırılgan bir vize serbestliği koşulsallığı karşılığında Türkiye’nin kapsamlı bir uyum programının yüksek maliyetlerini kabul etmesinde iç siyasi dinamiklerin etkili bir faktör olarak potansiyeline işaret etmektedir. Bu çalışma, Avrupa Birliği politikalarına uyum konusunda, iç siyasi dinamikler ve kamuoyunun, koşulsallık mekanizması aracılığı ile, karar alıcılar ve Türk dış politikası üzerindeki olası etkilerini ortaya koymaya çalışmaktadır.

Anahtar kelimeler: Türkiye-AB İlişkileri, dış politika analizi, Ortak Göç Politikası, koşulsallık, vize muafiyeti

\section{Readmission Agreement and Visa Liberalization with the EU: Understanding Turkey's Foreign Policy Choices}

\begin{abstract}
This article aims to make sense of Turkey's foreign policy choices in relation to adaptation to Common Migration Policy of the EU. First analysis through Europeanization models shows that cost and benefit calculations reveal the potential of domestic political dynamics as an influential factor for Turkey's consent to the high costs of a broad adaptation program in return of a vulnerable visa liberalization conditionality. This study attempts to explain how the internal dynamics (opportunity structures) and
\end{abstract}

* Yrd. Doç. Dr., Kocaeli Üniversitesi. E-posta: melike.kose@kocaeli.edu.tr 
public opinion through the conditionality mechanism may affect the policy-makers and thereby the Turkish foreign policy decisions.

Keywords: Turkey-EU Relations, Common Migration Policy, foreign policy analysis, conditionality, visa liberalization

\section{Giriş}

Avrupa Birliği’nin ( $\mathrm{AB}$ ) en önemli ortak göç politikaları ihraç stratejilerinden biri olan Geri Kabul Anlaşmaları ile vize teşvikinin eşlenmesi, bu konudaki müzakereler on yıldır başarısız bir şekilde devam etmesine rağmen, Türkiye’ye ancak 2012 yllında önerilebilmiştir. Öte yandan, Türkiye ise "vizesiz Avrupa" önerisi karşısında dış politika tercihinde önemli bir değişikliğe gitmiş, önce AB’nin göç politikalarına uyum için taleplerini, belli koşullar altında, karşılayacağını açıklamış ve nihayetinde 2013'ün Aralık ayında Avrupa Birliği Geri Kabul Anlaşması’nı (ABGKA) imzalamıştır. Türkiye’nin dış politika tercihlerindeki bu değişim ise Avrupa Birliği’nin hem üyelik hem vize alanında zayıflayan koşulsallık kredibilitesi ve Türkiye’nin son yıllarda Avrupa Birliği Adalet Divanı (ABAD) kararları ile serbest dolaşıma ilişkin kazanımları dikkate alındığında oldukça şaşırtıcıdır.

$\mathrm{Bu}$ makalenin temel amacı Avrupalılaşma kapsamındaki uyum kararlarında etkili olan faktörleri göç politikalarına uyum çerçevesinde ve Türkiye örneği özelinde anlamaya çalışmaktır Çalışmamızın ana sorusu AB Göç Politikasına uyum ve Geri Kabul Anlaşmasını imzalama hususunda Türkiye’nin değişken dış politika tercihlerini etkileyen temel faktörlerin neler olduğudur. Bu tür bir analiz, koşulsallığın hem güven kaybı hem de benzer kazanımlara imkan verecek dış politika alternatifleri nedeni ile zayıfladığı koşullar altında AB’nin belirli politikaları ihraç etme çabasının hedef ülkelerde nasıl sonuçlar doğurduğunu ortaya koyma şansı da vermektedir. Makale vize koşulsallığının, hem gücü hem erozyonu anlamında, ilk ve doğrudan etkisini hedef ülkenin kamuoyu üzerinde yaratacağı ön varsayımı altında; iç siyasi dinamiklerin dış politika kararları üzerindeki rolünü açıklamaya çalışmaktadır. Bu anlamda çalışmanın altta yatan hipotezi şu şekilde ifade edilebilir: "gerek AB'nin vize uygulamalarının gerekse sürekli inişçıkış arz eden AB-Türkiye ilişkilerinin yarattığı toplumsal ve siyasal hassasiyet doğrultusunda; iç siyasi dinamiklerin ve özellikle sosyo-psikolojik faktörlerin, Türkiye’nin bu dış politika alanındaki karar alma sürecinde, kamuoyu, medya ve politikacıların sübjektif algıları aracıllğıyla, önemli bir rol oynaması beklenmektedir."

$\mathrm{Bu}$ çalışma öncelikle aday ülkelerin Avrupa Birliği politikalarına hangi koşullar altında uyum sağladığını açıklamaya çalışan rasyonel modellerden arasında özellikle göç alanı için geliştirilen Lavenex \& Uçarer modelini kullanarak Türkiye’nin son dönemde değişen politika tercihi değerlendirmektedir. Bu fayda-maliyet analizi, değişimi rasyonel anlamda tam olarak açıklayamasa bile adaptasyon kararında belirleyici faktörler olarak iç siyasi dinamiklere ve kamuoyu etkisine işaret etmektedir. Yerel fırsat yapısı adı verilen bu faktörde kamuoyu desteği özel bir öneme sahiptir. 
İç siyasi dinamiklerin nasıl ve ne yönde bir rol oynadığına dair anlayışımızı derinleştirmek adına, makalenin ikinci kısmında gerek AB’ye ilişkin kamuoyu yoklamaları gerekse Schengen vize uygulamalarına özel proje sonuçlarının ışı̆̆ında incelemeler yapılmıştır. Ancak Türkiye’de AB’ye ve vize meselesine ilişkin algı ve tutumların dalgalı ve çelişkili bir görünüm arz ettiği sonucuna varılmıştır. Son bölüm, gerek bu alanda dış politikanın izlediği değişken yolu gerekse ilgili siyasi aktörlerin açıklamalarını analiz ederek bu çatışmalı algı ve tutumların siyasi aktörlerde ve karar alıcılarda yansıma bulup bulmadığı sorusunu cevaplamaya çalışmaktadır. Bu çerçevede, ulaşılan önemli sonuçlardan biri, kamuoyundaki olumlu ve olumsuz farklı yaklaşımların, güvendeki karşılıklı erozyonunun ve Türkiye’ye özgü dış politika alternatiflerinin (ABAD kararlarının ortaya koyduğu vizesiz seyahat hakları) birlikte koşulsallıkta bir sarkaç etkisi yaratarak salınımlı ve değişken dış politika stratejilerine yol açtığıdır.

\section{Avrupalılaşma Kuramlarına Kısa Bakış}

Türkiye’nin vize serbestleştirmesi karşılığında Geri Kabul Anlaşması’nı imzalamasını ve AB göç politikasına uyum sağlamaya rıza göstermesini bir dış politika tercihi olarak anlayabilmek için çeşitli teorik alternatifler bulunmaktadır. Bunlar arasında özellikle Avrupa entegrasyonunun ulusal siyasi yapılar üzerinde değişken etkisini açıklamaya çalışan, üye ve üye olmayan ülkelerin neden $\mathrm{AB}$ kurallarını benimseyip taleplerini yerine getirdiğini inceleyen 'Avrupalılaşma'^ (Bauer vd, 2007:406; Hix ve Goetz, 2000) teorileri, 'hangi koşullar altında üye olmayan devletler AB kurallarını benimserler ve politika tercihlerini AB’nden gelen dış baskılara ve ya teşviklere göre oluştururlar?' sorusuna cevap aramaları ve AB’nin uyum sağlama baskılarına verilen ulusal reaksiyona yoğunlaşmaları nedeni ile bu makalenin konusu için uygun kavramsal çerçeveyi sağlayabilirler.

Avrupalılaşma alanındaki araştırmaların çoğu AB’nin ülkeler üzerindeki etkisini değerlendirirken hem ulusal hem de uluslararası düzlemdeki koşulları ve faktörleri dikkate alır. Uluslararası seviyede, AB’nin kullandığg farklı strateji ve enstrümanlar ile onları nasıl uyguladığı incelenir. AB’nin aday ülkeleri etkilemek için en önemli stratejilerinden biri koşulsallıktır. Koşulsallık, $\mathrm{AB}$ üyeliği gibi pozitif teşviklerin üye olmayan ülkelerin belirli AB kurallarını benimsemeleri karşılığında bir ödül olarak kullanılmasıdır. Ancak koşulsallık stratejisi yeknesak ve homojen bir uygulama değildir. Konu alanına, hedef ülkelere göre ve zaman içinde değişkenlik gösterir.

$\mathrm{Bu}$ araştırmaların genel kuramsal çerçevesini esas olarak uluslararası ilişkiler ve karşılaştırmalı siyaset alanlarından uyarlanan iki temel yaklaşım, rasyonalist kurumsalcılık ve inşacı (sosyolojik) kurumsalcılık, arasındaki tartışma oluşturmaktadır (Sedelmeier, 2011: 11). Rasyonalist kurumsalcılık, sonuçlar mantığını (March ve Olsen, 1989) başka bir deyişle akılcı fayda-maliyet analizini politika tercihinin arkasında yatan neden olarak görür. Buna göre aktörler belirli şartlar altında faydalarını maksimize edecek olan alternatifi seçerler (Schimmelfennig, 2012: 5,6).

1 Avrupalılaşma ulusal kurumlarda ve politika uygulamalarında gerçekleşen Avrupa entegrasyonuna atfedilebilecek değişim süreci olarak tanımlanabilir. 
Rasyonalist model böylece AB’nin aday ülkeleri etkilemek için koşulsallığı kullanımına ve uyumun ulusal maliyetine odaklanır. $\mathrm{AB}$ politikalarına uyum, hedef ülkenin fayda-maliyet hesaplamalarını değiştiren yaptırımlar ve ödüller aracılığı ile sağlanabilir. Ancak, içerideki uyum maliyetleri uluslararası ödüllerden daha yüksek olmamalıdır, aksi halde koşulsallığın uygulandığı rasyonel devlet itaat etmeyecek ve kurallara uymayacaktır (Schimmelfennig, 2012:8). Koşulsallığın etkin olabilmesi için $A B$ ’nin taleplerinin net olması, inandırıcı/güvenilir olması (kredibilite), AB’nin daha üstün pazarlık gücüne sahip olması, koşulsallığın ödülünün yakın/ orta vadede elde edilebilir olması gibi çeşitli şartlar vardır (Sedelmeier, 2011: 12-14). Öte yandan AB’nin uyum baskısı, fayda-maksimize eden ulusal aktörler için fırsat yapısını değiştirerek ve içerdeki değişikliği gerçekleştirecek hukuki ve siyasi kaynakları sunarak bazı ulusal aktörleri (elitler, sivil toplum ya da hükümet gibi) kuvvetlendirir. Ulusal düzlemde, AB’nden politika transferinin gerçekleşmesinde uyum maliyetlerinin siyasi aktörler için göze alınamayacak kadar yüksek olmaması, politika alanında değişimi veto edebilecek aktör sayısının düşük olması ve idari kapasitenin talepleri yerine getirebilecek düzeyde olması gibi şartlara bakılır.

Sosyolojik kurumsalcılık (normatif model), AB’nin ulusal etkisinin yerel aktörlerin, AB normlarını meşru olarak içselleştirdikleri bir sosyolojik sürecin sonucunda oluştuğunu iddia eder. $\mathrm{Bu}$ modelde aktörler uygunluk mantığını kullanarak gerçekten bu kuralların uygun ve meşru olduğunu düşündükleri için uygularlar. Uygunluk mantığı ise hükümetler arası etkileşimler (pazarlık ve ya ikna) ve ya hedef devletteki toplumsal aktörlerin ulus-aşırı süreçler yoluyla $A B$ ile özdeşleşmesi ve sosyal öğrenme yoluyla ortaya çıkar. Bu modelde, AB kuralları ile yerel kültürel anlayışlar (ve informal kurumlar) arasındaki normatif rezonans (uyum), yerel aktörlerin $A B$ kuralları doğrultusunda çıkar ve kimliklerini yeniden tanımladığı bir sosyal öğrenme sürecine girip girmeyeceğine ilişkin kilit aracı faktördür (Schimmelfennig, 2012:7,8). İnşacı model, ikna ve sosyalizasyonu AB’nin yerel etki yaratmadaki temel stratejisi olarak görür. İkna ve sosyalizasyon stratejisinin etkili olabilmesi için AB'nin teşvik ettiği kuralların ve bu kuralları teşvik etme biçiminin/sürecinin meşru olması ya da aday ülke tarafından o şekilde algılanması gerekmektedir. İki tip modelin ortaya konması onların karşılıklı olarak dışlayıcı olduğunu göstermez aksine bu modeller bir vakayı açıklamakta tamamlayıcı olarak kullanılabilirler (Sedelmeier, 2011: 11-16).

\section{AB Ortak Göç Politikasına özel bir rasyonel analiz çerçevesi: Lavenex \& Uçarer Modeli}

Avrupalılaşma alanında bugüne değin birçok model geliştirilmesine karşın ${ }^{2}$ on yıldan fazladır önemli bir araştırma alt alanı haline gelen Ortak Göç Politikasının (OGP) üye-olmayan ülkelere transferi konusunda en kapsamlı model Lavenex ve Uçarer (2004) tarafından sunulmuştur. Lavenex \& Uçarer modeli fayda-maliyet mantığının farklı koşullarda nasıl sonuçlar verebileceğini ayrıntılı biçimde gösterir. Avrupalılaşma kapsamındaki politika transferi öncelikle ülkelerin $\mathrm{AB}$ ile kurdukları kurumsal ilişkinin düzeyine bağlı olarak, politika uyumunun bir zorunluluktan

2 Türkiye’nin farklı alanlardaki Avrupalılaşma sürecini, göç politikaları dahil olmak üzere, ayrıntılı olarak inceleyen çok kapsamlı çalışmalardan ikisi Ali Tekin ve Aylin Güney editörlüğünde yapılmıştır. Bkz. Ali Tekin ve Aylin Güney (2015). The Europeanization of Turkey: Polity and Politics. New York: Routledge ve Ali Tekin ve Aylin Güney (2016). The Europeanization of Turkish Public Policy: A Scorecard. New York: Routledge 
mı yoksa gönüllü bir tercihten mi kaynaklandığına göre iki ana gruba ayrılır. Böylece aday olmayan ülkeler de model kapsamı içine alınmış olur. İlk grupta AB'ye karşı bir yükümlülükten kaynaklanmayan ancak ulusal çıkarların adaptasyonu tetiklediği durumlarda üçüncü ülkeler ya $\mathrm{AB}$ kurallarının üstünlüğüne ikna olup yerel problemleri daha etkin şekilde çözmek için onları benimserler (tek tarafl politika öykünümü) ya da uyum sağlamamak net maliyetler ve zararlar yaratacaksa negatif dışsal etkiler nedeniyle yine göç politikasına adapte olurlar. İkinci grupta ise AB’nin politika girişimcisi olarak hareket ettiği örnekler yer alır. Politika alanındaki işbirliğinin $\mathrm{AB}$ ile üçüncü ülke arasında ikili bir anlaşma ile düzenlenmesine koşulsallı adaptasyonu adı verilir. Bir zorunluluğun altında ve doğrudan $A B$ etkisi ile politika transferinin gerçekleştiği bu tür durumlarda politika transferi mevcut yerel problemlerle baş etmede daha etkin bir yol olarak görülürse ve bu nedenle üçüncü ülkenin çıkarlarına uygun ise isabetli koşulsallı; yaratacağı ciddi maliyetler nedeni ile ülke çıarlarına ters düşmesine rağmen başka teşviklerle telafi ediliyorsa, daha otoriter biçimde ortaya çıkan bu transfere isabetsiz koşulsallık adı verilir (Lavenex ve Uçarer, 2004: 420-422).

Her tip için nasıl sorusu kadar neden sorusuna da cevap arayan model, politika transferinin gerçekleşip gerçekleşmeyeceğini etkileyen dört ana faktör ortaya koyar. İlk olarak AB politikaları ile üçüncü ülkedeki yerel düzenlemelerin birbirine ne kadar uyumlu olduğuna ve bu politika alanındaki fonksiyonel karşılıklı bağımlılık derecesine bakmak gerekir. Örneğin AB’nin koyduğu şartlar ve yerel durum arasında yüksek oranda ya da artan şekilde bir uyumsuzluk var ise gönüllü adaptasyon için ihtimal azdır. Diğer yandan, eğer politikalar tamamen uyumlu ise o durumda zaten politika transferi ortaya çıkmayacaktır. Ayrıca bir ülkedeki yerel firsat yapısı (iç siyasi dinamikler) belirleyici faktörlerden biridir. Yerel fırsat yapısı bir ülkedeki stratejik çıkar kümelenmelerini ve onların karşılıklı ilişkilerini; değişimi veto edebilecek aktörleri ve siyasi değişimi sınırlayabilecek diğer kurumsal özellikleri kapsar. Örneğin eğer ulusal kamuoyu adaptasyon hakkında geniş ölçüde lehte ise pozitif bir fırsat yapısından bahsetmek mümkündür; eğer ulusal çıkar kümelenmeleri ve/ve ya kurumsal kontekst politika değişikliğine muhalif ise yerel fırsat yapıları negatiftir diyebiliriz. Son olarak adaptasyon yokluğunun maliyetine bakmak gerekir. Uyum için yerel koşullar uygun olmadığında ve ya güçlü kamuoyu karşıtlığı olduğunda normalde ülkeler politika değişikliğine gitmemeyi tercih edecek olsalar da uyumsuzluk halinde beklenen maliyet çok yüksekse buna mecbur kalabilirler. Modelde koşulsallık bu noktada devreye girer ve uyum sağlamama maliyetlerinin manipülasyonu ile itaati sağlama aracı olarak tanımlanır (Lavenex ve Uçarer, 2004: 424-425).

\section{Arka plan ve temel kavramlar: AB'de Geri Kabul Anlaşmaları ve Vize Teşviki Eşlemesi}

Avrupa Topluluğu’nun imzaladığı geri kabul anlaşmaları (GKA) 1950'li yıllara kadar uzansa da esas olarak AB’nin doğu sınırı boyunca bir güvenlik kuşağı yaratmak amacı ile 1990'larda Orta ve Doğu Avrupa (ODA) ülkeleri ile ve 2000 ’lerden beri farklı üçüncü ülkelerle imzalanan ve vatandaş olmayan kişileri de kapsayan GKA'lar Avrupa Göç Politikasının önemli bir 
enstrümanıdır (Bouteillet-Paquet, 2003:359,360; Carrera ve Kirişçi, 2004: 9). AB ve diğer ülkeler arasında yapılan geri kabul anlaşmaları bu ülkelere topraklarından geçerek $A B$ ülkelerine ulaşan kendi vatandaşlarını ve üçüncü ülke vatandaşlarını geri kabul etme kabul etme zorunluluğu getirir ve bu sürecin işlemesi için ayrıntılı olarak operasyonel ve teknik kriterleri ortaya koyar (Billet, 2010; Boswell, 2003:622). GKA'ların temel amacı AB’ye yasa dışı göçün kontrol altına alınabilmesi ve yasadışı göçmenlerin kendi ülkelerine ve ya $A B$ 'ye gelirken geçiş ülkesi olarak kullandıkları ülkelere iadesini kolaylaştırmaktır.

Günümüze değin GKA'lar kontrol yükünü Avrupa Birliği sınırlarından Güney ve Doğudaki geleneksel transit ülkelere kaydırarak esas kabul ülkelerinden mülteci akımlarının yeniden dağllımına neden olmuştur (Levenex, 2001: 29; Roig ve Huddleston, 2007: 370). Üçüncü ülkelerle bu tür antlaşmalar müzakere etme ve tamamlama yetkisini AB'ye transfer eden Amsterdam Anlaşması (1999) ile ağırlığı ve etkinliği artan GKA'ları, yasadışı olarak kalmakta olan üçüncü ülke vatandaşlarının $A B$ topraklarından ihracı ve böylece göç akımlarının yönetimi için Birliğin başlıca ulus üstü aracı haline gelmiştir (Kruse, 2003: 10). Böylece AB yasadışı göçten kaynaklı iç güvenlik endişelerini, komşu ülkeleri sınır kontrollerini sıkılaştırmaya zorlayarak hafifletirken, bu ülkeleri yasadışı göçmenlerin yaratabileceği yük ve maliyetleri paylaşmaya zorlar.

AB’nin vize kolaylaştırma teşvikini GKA'lar ile eşlemesi diğer ülkeleri bu anlaşmaları imzalamaya ikna için fayda-maliyet hesaplamalarını değiştirmektir. Böylece Lavenex’in önemle üzerinde durduğu uyum sağlamama maliyetinin koşulsallık ile manipüle edilerek arttırılmasına iyi bir örnek teşkil etmektedir. Vize koşulsallığı o kadar etkili bir vaattir ki AB bir süre sonra taleplerini GKA'lardan göç politikasının diğer birçok unsuruna ve Adalet ve İçişleri politikasına kapsamlı uyuma kadar genişletmiştir. Vize kolaylaştırma teşviki özellikle belirli kategorilerdeki kişiler için kısa-süreli çok-girişli vize almayı zaman, maliyet ve gerekli başvuru dokümanları açısından kolaylaştırırlar. Kapsamı göreceli dar olan bu teşvikin esas gücü uzun vadede vize serbestleştirme vaat etmesinde yatar. Vize serbestleştirme ise Schengen alanına ve bu alan içinde vizesiz seyahat edebilme ve 90 güne kadar kalabilme demektir ve tüm ilgili ülke vatandaşlarını kapsar. Vize kolaylaştırma anlaşmaları ilgili ülke ABGKA'yı imzalayıp yürürlüğe soktuktan sonra imzalanır. Vize serbestleştirme ise ancak $\mathrm{AB}$ tarafından yakından kontrol edilen bir süreç sonunda ABGKA’nın etkin şekilde uygulanması, gelişmiş sınır yönetimi, organize suçlar, yolsuzluk ve yasadışı göçle, azınlık politikalarının reformu gibi koşulların yerine getirilmesi karşılığında verilmektedir (Trauner ve Krause, 2008(a): 421).

Kendi vatandaşları için vize mecburiyetinin kaldırılması ile yabancıların geri kabul zorunluluğunu bağlamak ilk olarak Orta ve Doğu Avrupa (ODA) ülkeleri ile yapılan ikinci nesil GKA'larında başarılı şekilde denendi: bir başka deyişle ODA ülkeleri GKA'ları onaylamayı kendi vatandaşları için vize mecburiyetinin kaldırılması karşllığında kabul ettiler (Bouteillet-Paquet, 2003: 364). Elbette, üyeliğin cazibesi ODA ülkelerinin göç akımlarında daha fazla sorumluluk almasında önemli bir rol oynadı. Daha sonra sırası ile Makao, Hong Kong, Rusya ve Ukrayna için (Trauner ve Krause, 2008(a): 415) GKA imzalanması karşıllı̆ında vize kolaylaştırma anlaşmaları imzalanarak eşleştirme bir strateji haline geldi. Nihayetinde eşleştirme Batı Balkanlarla kurulan ilişkilerde 
geçici bir stratejiden standart bir politika aracına dönüştü.

Batı Balkanlara önce GKA imzalanması karşıllğında belirli kategorideki kişiler için daha hızlı, ucuz ve basit vize rejimleri uygulamayı içeren vize kolaylaştırma teşviki önerildi ve $A B$ ile Balkan ülkeleri arasındaki GKA ve VKA'lar 1 Ocak 2008'de yürürlüğe girdi. Daha sonra sunulan yol haritalarında ise vize serbestleştirme teşviki karşılığında göç politikalarını tamamen $A B$ ile uyumlaştırmaları ve güvenlikle ilgili birçok farklı zorunluluğu yerine getirmeleri istendi. Konsey ve Komisyon tarafından yakından izlenen bu sürecin sonunda yol haritasındaki şartların etkin ve tutarlı şekilde yerine getirildiğine karar verildiğinde ise Makedonya, Karadağ ve Sırp vatandaşları için 19 Aralık 2009'dan itibaren, Arnavutluk ve Bosna-Hersek için 7 Ekim 2010'dan itibaren biyometrik pasaportlu ülke vatandaşlarını kapsayacak vizesiz seyahat rejimi benimsendi.

\section{Sui Generis Bir Ülke ile Avrupalılaşma modellerini test etmek: Çıkarlar mı sosyalizasyon mı?}

\section{Kurumsal ilişsi düzeyi}

Lavenex-Uçarer modeli önce ülkeleri AB'yle kurdukları kurumsal ilişki düzeyine göre gruplamaktadır. Türkiye’nin 2012'de vize koşulsallığı önerilmeden önceki pozisyonu OGP uyumuna zorlanan diğer ülkelerle karşılaştırmalı olarak ele aldığında Lavenex Türkiye’yi KatılımÖncesi Ortaklık kategorisindeki Batı Balkan Ülkeleri ile aynı grupta tutsa da (Lavenex ve Uçarer, 2004: 432-433; Lavenex, 2011: 381-383) Türkiye’nin bu kategoriye tam uymadığı açıktır. Türkiye Batı Balkan grubundaki aday ülkelerden çok daha önce ve ODA ile neredeyse aynı dönemde resmi adaylık statüsüne geçmiş bir ülkedir. Ancak ODA ülkeleri ile de aynı gruba konulması zordur, ODA'dan çok daha önce $\mathrm{AB}$ ile ortaklık anlaşması çerçevesinde sıkı bir kurumsal ilişkisi kurmuştur. Adaylık başvurusunu da 1987'de tüm bu adaylardan çok önce yapmıştır. Buna rağmen OGP’ye uyum sürecinde $A B$ üyelik koşulsallığına ağır bir kredibilite ve güven kaybı eşlik etmesi nedeni ile Türkiye ODA ülkelerinden ayrılmakta; böylece muhtemelen, üyelik koşulsallığındaki belirsizlik nedeni ile, Lavenex tarafından Batı Balkan ülkeleri ile aynı grupta değerlendirilmektedir.

Fakat vize teşvikinin 2012 Haziran’ına kadar Türkiye’ye önerilmemesi göz önüne alındığında bu da OGP açısından doğru bir değerlendirme olmamaktadır. Bu tarihe kadar Türkiye’nin göç politikaları anlamında durumu Batı Balkan ülkelerinden çok, Lavenex’in Avrupa Komşuluk ortaklığı adını verdiği ve AB'ye kurumsal ve ilişkisel uzaklığı anlamında 4. çepere giren ülkelere yakındı. 4.çeper ülkeleri ile GKA'ların imzalanmasındaki başarısızlığın en önemli sebebi ise, Lavenex' in net ifadesi ile vizesiz seyahat ve ya benzeri bir koşulsallık olmaksızın 'Birliğin çıarları tarafından dikte edilen tek taraflı yaklaşımın darlı̆̆’’ idi (Lavenex ve Uçarer, 2004: 433).

Şimdi önümüzde duran soru ise şudur: AB’nin vize serbestleştirme teşvikini en nihayetinde 2012 yılında Türkiye’ye de sunması uyumsuzluk maliyetlerini arttırarak GKA dâhil olmak üzere 
göç politikasına ilişkin kapsamlı yükümlülükler altına girme tercihini Türkiye için rasyonel bir tercih haline getirmekte midir? Ya bundan da öte değișen koşullar nedeni ile isabetli bir koşulsallıktan söz etmek mümkün müdür? 2012'de vize teşviki karşılığında ABGKA imzalamayı kabul edilebilmesi için daha da ötesinde vize serbestleştirme karşllı̆ında daha da kapsamlı bir göç politikası uyumuna gidilebilmesi için gerekli ama kendi başına yeterli olmayan üç olasıllı vardır. Bunlardan ilki Türkiye’nin göç ile ilgili koşullarında meydana gelen radikal değişiklikler sonucu uyumun kendiliğinden ve koşulsallıktan bağımsız olarak ülkenin çıkarlarına hizmet eder hale gelmesi (fayda-maliyet analizi); ikincisi bu alandaki Avrupalılaşmanın elitlerin, ilgili bürokratların ve siyasi aktörlerin bazı değer ve ilkeleri içselleştirmesi sonucu meydana gelmesi (sosyalizasyon); üçüncüsü ise vize koşulsallığının tüm çıkar hesaplamalarını değiştirecek kadar bir güçlü fayda algısı yaratmasıdır (koşulsallığın gücü).

\section{Fayda-maliyet analizi}

ABGKA'lar yukarıdaki tarihsel gelişimi anlatılırken değinildiği gibi, üçüncü ülkeler için ağır maliyet ve külfetler yaratan anlaşmalardır. Hatta birçok uzman tarafından açıkça 'Avrupamerkezli' ve tek taraflı olarak nitelenirler (Trauner ve Kruse, 2008(b): 24, 29). Genellikle geri dönüş prosedürü, transit dönüş düzenlemeleri, sorumluluk kriteri, kanıt standardı, zaman sınırlarına ilişkin koşullar devletleri uygulamada ciddi zorluklarla karşı karşıya bırakırken, göçmenlerin ve sığınmacıların yakalanması, bir yerde toplanması ve geri gönderilmesi, eksiksiz ve adil bir sığınmacı belirleme işleminin uygulanması açısından da ağır sorumluluklar yüklemektedir. Yasadışı göç ve sığınmacılar problemli alanında külfetin $A B$ dışındaki ülkelere kaydırılması politikası olarak yorumlanan ABGKA'ların üçüncü ülkeler için ağır sosyo-ekonomik yük yaratırken, istihdam piyasalarını ve toplumların toleransını aşırı zorlamaları muhtemeldir (Roig ve Huddleston, 2007: 380).

Avrupa Birliği açısından önemli bir transit ülke olan Türkiye için ABGKA’nın yukarıda belirtilenlerden farklı sonuçlar doğurması için bir neden yoktur. Türk yetkililer müzakerelerin sürdüğ̈̈ uzun yıllar boyunca geri kabul şartının, özellikle ciddi bir üyelik ümidi ve AB’nin Türkiye ile bu alanda bir dayanışması yokken, Türkiye’yi $\mathrm{AB}$ yasa dışı göçmenler ve reddedilen sığınmacılar için bir tampon bölgeye dönüştüreceğinden korktuklarını ifade etmişlerdir (Soyaltın, 2013: 3-4). Türkiye her yll giderek daha çok göçmen için hedef ülke haline gelse de 2012 UTSAM raporuna göre, Türkiye halen göçmenler tarafından Avrupa ülkelerine geçiş için yoğun biçimde (\%62) transit ülke olarak kullanılmaktadır (Uluslararası Terrörizm ve Sınıraşan Suçlar Merkezi [UTSAM], 2012: 25).

1999 yllından beri resmi aday olan ve 2005'den beri üyelik müzakereleri devam eden Türkiye’nin Lavenex-Uçarer modeline göre zorunlu uyum kategorisinde olduğu tek konu elbette ABGKA imzalanması değildir. Türkiye’nin OGP ile Adalet ve İçişleri Alanlarında zorunlulukları vize serbestleştirme önerisinden önce de çokça tartışılmış ve Türkiye 1999'dan beri AB'ye uyum çerçevesinde göç ve iltica alanında birçok idari ve yasal reform gerçekleştirmiştir. Bunlardan en önemlilerinden biri Nisan 2013'de yürürlüğe giren Yabancilar ve Uluslararası Koruma 
Kanunu'dur. Dolayısıyla yasadışı göçün yarattığı sıkıntılarla baş edebilmek için modernizasyon ve reform kendiliğinden Türkiye’nin çıkarlarına görünmektedir. Acaba Bürgin’in konuya ilişkin makalesinde (Bürgin, 2012) ifade ettiği gibi ${ }^{3}$ isabetsiz olacak koşulsallık şartların değişmesiyle isabetli koşulsallığa mı dönüşmüştür: başka bir ifade ile, 2012'ye gelindiğinde hem Türkiye’ye yeni ve etkili bir teşvik önerilmiş hem de karşılığında istenilen zorunluluklar değişen şartlarla ülke çıkarlarına uygun hale mi gelmiştir?

Aslında Türkiye’nin belli aralıklarla gerçekleştirdiği reformlar zamanlamasını kendi seçerek yaptığ reformlardır. Bu anlamda bu reformların AB için değil, AB’yle ilişkiler kötüleşmesine rağmen Türkiye’nin kendi çıkarlarına uygun bulması nedeniyle gerçekleştirildiği ilk bakışta akla uygun gelmektedir (Vukašinović,, 2011: 162). Ancak Türkiye bu reformları seçici bir şekilde, kendi çıkarlarına uygun olanları, kendi tercih ettiği zamanlamalarla gerçekleştirmiştir (Tolay, 2012: 3962).

Türkiye'nin bugüne kadar ulusal çıkarlarına uygun olmağı için uymamakta direndiği ve vize teşviki için imzalanan yol haritasında uymak zorunda kalacağı birçok koşul vardır. Türkiye’nin çıkarları açısından önemli itiraz noktalarından biri iltica başvurularında Türkiye’nin uyguladığı coğrafi sınırlama kuralının kaldırılmasına yöneliktir. Özellikle kendisine komşu ülkelerdeki radikal değişim ve savaşlarda sık sık mülteci akımına uğrayan Türkiye için Avrupa ülkeleri dışından gelen sığınmacılara mülteci statüsü tanımaması önemli bir ulusal çıkar meselesi olarak görülmektedir. Bir başka $\mathrm{AB}$ talebi ise sivil bir sınır yönetim birimi kurulmasıdır ki Türkiye güvenlik endişeleri ve terörizm ile mücadele planları çerçevesinde buna karşı çıkmaktadır (Soyaltın, 2013). Schengen vize rejiminin benimsenmesi (Council Regulation (EC) No 539/2001) Türkiye’nin komşu ülkelerle son yıllarda yaptığı tüm vize anlaşmalarını iptal etmesi demektir (Toksöz vd, 2012: 19). Schengen negatif vize listesine bu şekilde uyum sağlanır ve Türkiye-AB arasında nihayetinde vize serbestleştirmeye gidilmez ise Türkiye kendisi de negatif listede olduğu halde negatif listeyi uygulayan tek ülke olacak (Kirişçi, 2005: 349) ve aynı zamanda Türkiye’ye girişi zorlaştırarak "kaçak göç” sorununu kötüleștirebilecektir. Dolayısıyla bandrol uygulamasının kalkması ve Türkiye’nin kısıtlayıcı Shengen vize rejimini kabul etmesi Türkiye’nin ekonomik çıkarlarıyla uyumlu değildir (Kirişçi, 2007).

Tüm bunlara vize serbestleştirme için çizilen yol haritasında belirtilen düzensiz göçmenlerle ilgili yapması gereken idari reformların getireceği ağır yük eklenmelidir. Sığınmacıların barınma ve yaşam ihtiyaçlarının karşılanmasından, çok sayıda eğitimli personel tahsisinin maliyetine ve etkin bir sınır kontrolünün masraflarına kadar ağır bir ekonomik yük Türkiye’yi beklerken AB’nin mali yükün ne kadarını paylaşacağı hala netleşmemiştir. IKV değerlendirme notunda açıkça 'Asimetrik yapısından ötürü Geri Kabul Anlaşması, açıkça ve orantısız şekilde Türkiye’nin zararınadır; zira Türkiye geri kabullerle ilgili yükümlülüğün büyük kısmını omuzlamak durumunda kalacaktır (özellikle maddi açıdan)' denmektedir' (Özsöz, 2013: 8).

3 Bürgin’e göre zaten sınır yönetimini ve mülteci politikasını reformlarla modernize etmek isteyen Türkiye bu konuda $\mathrm{AB}$ ile işbirliği yaparak destek almayı tercih etmektedir. 


\section{Sosyalizasyon: çıkarlar mı değerler mi?}

Göç politikasının dışsallaştırılmasına ilişkin Lavenex-Uçarer modeli değer sosyalizasyonunu uyuma neden olan kategoriler arasına almaz. Ancak AB'deki kuralların ve yapıların ihracının ulusal çıkarlara uygun düşeceğini ve mevcut problemlerle daha etkin çözüm yolları sunacağını anlayan yerel aktörler yenilikçi ve başarılı AB politikalarına öykünerek seçici biçimde reformları gerçekleştirirler (politika öykünümü). Çıkarlara dayalı bir hesaplamaya dayanan bu durum değer sosyalizasyonu ile karıştırılmamalıdır. Aksine Lavenex AB’nin uzun süredir sürdürdügü göç politikaları ihraç stratejisinin uluslararası alanda normatif aktör olarak oynadığı role zarar verebileceğine açıkça dikkat çekmektedir (Lavenex ve Uçarer, 2004: 437). AB Ortak Göç Politikası ve bu politikanın ihracı insan hakları ve uluslararası hukuk gibi normatif unsurların ikinci plana atıldığı bir güvenlikleştirme temel eğilimi taşımaktadır ve bu anlamda meşruluğu tartışmalıdır.

Türkiye’nin gerçekleştirilen bazı reformlar, özellikle Yabancılar ve Uluslararası Koruma Kanunu, düzensiz göçmenlerin ve sığınmacıların haklarını korumaya ve iyileştirmeye hizmet etmiştir ve bu anlamda bir değer sosyalizasyonundan bahsedilebilir (Kirişçi, 2012: 64). Ancak birçok önde gelen yazar AB'nin etkisi kabul edilse bile diğer uluslararası kurumların artan etkilerinin ${ }^{4}$ altını çizmektedir (Aydın ve Kirişçi, 2013). Burada Türk yetkililer, UNCHR, IOM ve diğer sivil toplum kuruluşları arasındaki ilişki ve bilgi alışverişi önemli rol oynamıştır (Aydın ve Kirişçi: 380). ${ }^{5}$ Sosyalizasyonun tersine iltica başvurularını zorlaştırmaya ve hatta engellemeye çalışan bir Avrupa imajının Türkiye’ye uyum anlamında teşvik edici iyi bir örnek sunmadığı ve reformların Avrupa ile özdeşleşen değil kendini ondan farklı kılan aktörlerin çabası olduğu iddia edilmiştir (Kirişçi, 2012: 75; Tolay, 2012: 41). Öte yandan OGP’nin ihracı ise özellikle ABGKA'lar nedeniyle göçmen hakları açısından İnsan Hakları Örgütleri tarafından sıkça eleştirilmektedir. Aşağıdaki eleştiriler değer sosyalizasyonunu uyum kararında nedensel faktör olarak öne sürmeyi mantıksal açıdan sorunlu hale getirir.

Ortak AB Göç Politikasının dışsallaştırılması çoğu kez göçmenlerin haklarının ve sığınmacıların korunmasının bir kenara itilmesi anlamına geldiğinden AB geri kabul anlaşmaları insan hakları açısından sık sık sorgulanmaktadır (Human Rights Watch, 2006; Avrupa Konseyi Parlamenterler Meclisi, 2010; Euromedrights, 2013). Üçüncü ülkeye gönderilenlerin, geçtikleri ülkelerin herhangi birinde sığınma başvurusu imkânı bulamadan veya yaptıkları başvuru yeterince titiz biçimde ya da hiç incelenmeden kendi çıkış ülkelerine geri gönderilmeleri (zincirleme geri gönderilme) gibi bir risk söz konusudur (Avrupa Mülteciler ve Sürgünler Konseyi, 2007: 22). Diğer bir risk geri kabul edilen üçüncü ülke yurttaşının son derece sınırlı haklar ve fırsatlarla geçiş ülkesinde takılıp kalmasıdır (Lavenex, 2006: 334). Uluslararası örgütler AB’ni göçmenlerle ilgili kendi sorumluluklarını pazarlığın bir parçası olarak zayıf konumdaki ülkelere kaydırma konusunda ciddi biçimde uyarmaktadırlar (Avrupa Konseyi Parlamenterler Meclisi, 2010: 45). Türkiye ile imzalanacak ABGKA da insan hakları açısından çeşitli dezavantajlara sahip olma

42007 ve 2008'de artan mülteci başvurularının acil bir reform ihtiyacı yaratması ve artan geri göndermelerin Avrupa Konseyi, BM gibi uluslararası örgütler tarafından ağır şekilde eleştirilmesi reformların hızlanmasına yol açmıştır.

5 Burada çıkar anlayışının değişmesi en alt basamak olup, topluluğun kimliğini ve değerlerini benimsemek esastır. 
potansiyeli taşımaktadır (Uluslararası Af Örgütü, 2012: 8; İnsan Hakları Araştırmaları Derneği, 2013).

\section{Koșulsallığın Erozyonu}

2004'den beri AB’nin ABGKA imzaladığı ve göç düzenlemelerini ihraç ettiği ülkeler bunu ya güçlü üyelik koşulsallığı altında ya da vize muafiyeti karşılığında yapmışlardır. Türkiye için her iki koşulsallık da sorunludur. Öncelikle, ODA'da (ve daha az derecede Batı Balkanlarda) uyumsuzluk maliyetini arttıran ve koşulsallığı güçlendiren koşullardan en önemlisi Türkiye için geçerli değildir: Türkiye için AB'nin üyelik sözünün kredibilitesi genel olarak çok sorunlu devam eden üyelik müzakereleri nedeni ile ağır şekilde erozyona uğramıştır. AB ile ilişkiler de güven duygusunun sarsıntıya uğramış olması sadece üyelik koşulsallığını etkilemez; vize teşvikinin de güvenilirliğini zayıflatan ve Türkiye’ye özgü sayılabilecek önemli etmenlerden biridir.

$\mathrm{Bu}$ güven temeli zaten zayıf ilişkide vize koşulsallığını daha da zayıflatan, Batı Balkanlar ile kıyaslandığında uğranılan açıkça ayrımcı uygulamadır. Bu ülkeler ile görüşmeler 2006'da başlamadan önce, ABGKA ile vize kolaylaştırma arasındaki bağ AB üye devletleri tarafından kabul edildiğinden, bu iki anlaşma için müzakereler daha en başından birleştirilmesine rağmen bu teşvik Türkiye’ye, ABGKA görüşmeleri 7 yıl önce başlamış olmasına ve Türkiye'nin negatif tutumuna rağmen, yine Türkiye'nin ssrarıyla, 2012'de önerilebilmiştir. Oysa uyum sağlaması beklenen ülke nezdinde AB’nin kredibilitesinin olması koşulsallık mekanizmasının etkin şekilde işleyebilmesi için ön şartlardan biridir

Üyelik tartışmaları boyunca Türkiye`nin serbest dolaşım hakkından tam üyelik durumunda bile kalıcı olarak faydalanamayacağı yolunda çeşitli siyasi aktörler tarafından verilen mesajlar da vize teşvikinin inandırıcılığını zedelemiştir (Açıkmeşe, 2010: 145). Kıbrıs ve Fransa gibi ülkeler vize teşvikinin Türkiye'ye önerilmesi hususunda itirazlarını net ve açık biçimde ortaya koyarak 2011 yılında bu girişimi engellemişlerdir (Council of the European Union, 2011). Bu itirazların ilerleyen zamanlarda vize serbestleştirme sürecinin herhangi bir aşamasında da tekrarlanma ihtimali vardır. Türkiye’nin insani felaketler, iç karışıklıklar ve savaşlar sonunda uğradığı mülteci akımlarında AB’nden aradığı destek ve yardımı görememesi güven problemini ayrıca ağırlaştırmaktadır (Düvell, 2013).

\section{Türkiye'nin BATNA'sı Hayal mi? Fırsat mı?}

Türkiye'nin vizesiz seyahat imkanına ulaşmak için izleyebileceği alternatif strateji (Türkiye’nin BATNA'sı ${ }^{6}$ ) Ankara Anlaşması'ndan doğan serbest dolaşım haklarının açtı̆̆g yargı yoludur ve vize teşvikinin etkisini en azından zayıflatması beklenir. Hatta bazı uzmanlar Ortaklık Anlaşması ve Katma Protokol altında Türk vatandaşlarının zaten elde ettiği hakları engelleyecek ya da en iyi ihtimalle bu hakların aslında gereksiz kıldığı bir vize serbestleştirme anlaşmasının imzalanmasına karşı çıkmışlardır (Groenendijk ve Guild, 2011: 40).

6 Best Alternative to Negotiated Agreement: Müzakere edilen Anlaşmaya En iyi Alternatif 
AB'nin negatif vize listesinde olan Türkiye'nin durumu son yıllarda verilen ABAD kararları ${ }^{7}$ ile yeni bir boyut kazanmıştır (Karayiğit, 2011). ABAD Tüm ve Darı kararında yerleşim hakkı ile ilgili; Soysal davasında ise hizmetlerin serbest dolaşımı ile ilgili Türkiye’nin Ortaklık Anlaşması'ndan ve Katma Protokol'den doğan haklarını teyit etmiştir. Bu kararlarla ABAD açıkça Katma Protokolün yürürlüğe giriş tarihi olan 1 Ocak 1973 tarihinde hizmet sağlamak ve ya yerleşim (iş kurma) hakkını kullanmak üzere seyahat eden Türk vatandaşlarına vize veya benzeri şartlar getirmeyen ülkelerin bu tarihten sonra getirecekleri dolaşımı kısıtlayıcı ek şartların 1963 Ankara Anlaşması ile Katma Protokolün 41. maddesine göre serbest dolaşım ilkesinin açık ihlali olacağına karar vermiştir. Tüm ve Darı kararında ABAD, Katma Protokol'ün 41. maddesinin 1. fikrasının yorumunda, hükmün üye devlette yürürlüğe girdiği tarih itibariyle, ilk defa o ülkeye gelerek orada iş kurmak için yerleşmek isteyen Türk Vatandaşları için yerleşim özgürlügüünü kısıtlayan ve bununla bağlantılı olarak maddi ve usule ilişkin koşullar bakımından yeni ağırlaştırıcı hükümler getirilmesi yasaklanmıştır. Soysal Kararı ise daha geniş kapsamlı bir karar olup: herhangi AB ülkesine hizmet vermek üzere gelmek isteyen herhangi bir Türk vatandaşına ya 1973’te ya da ilgili üye devletin AB'ye katıldığı tarihte uygulananlarla aynı koşullar temelinde o üye devletin topraklarına giriş hakkı verir (Groenendijk ve Guild, 2011: 15-20).

Ancak aradan 3 yıldan fazla zaman geçmesine karşın Soysal kararı ne AB üye devletleri ne de kurumları üzerinde beklenen etkiyi ve zorlamayı yaratamadı. 1973'den önce üye olan 12 üye devletin tamamının 2-3 aya kadar kalışlar için vize şartını kaldırması beklenirken Avrupa Komisyonu 2009'daki hukuken bağlayıcı olmayan tavsiye kararında sadece Almanyada belli kategoriler $^{8}$ için Danimarka'da ise tüm hizmet sağlayıcılar için Türk vatandaşlarına yönelik vizenin kaldırılmasını istedi (European Commission, 2009). Öte yandan İngiltere Tüm ve Darı kararlarına uygun şekilde İngiltere'de iş kurmak isteyen Türk vatandaşlarının giriş serbestisi elde ettiği yeni bir prosedür benimsenmiştir (Tezcan ve Slot, 2010: 15).

Bu gelişmeler karşısında Mayıs 2011'de AB vize tüzüğünü (539/2001) değiştirecek yeni tüzük önerisinde, Avrupa Komisyonu Türkiye’ye vize konusunda istisna hükmü koymuş (European Commission, 2011: 17), Avrupa Parlamentosu ise Türkiye için vizelerin kaldırılmasını hizmet alımlarını kapsayacak bir zorunluluğa dönüştürmeyi teklif etmiştir (European Parliament, 2011). Ayrıca Avrupa Komisyonu’nu Schengen vizesine ilişkin tavsiye kararını Aralık 2012'de Hollanda'ya giriş yapmak isteyen Türk vatandaşlarından kısa süreli Schengen vizesi istenemeyeceğini kapsayacak şekilde revize etmiştir (European Commission, 2012).

Ancak 2013 yılında gelindiğinde Avrupa Parlamentosu AB Vize Tüzüğünde değişiklik yapacak yasa taslağından Türkiye lehine kendi önerdiği tüm net vize istisnalarını kaldırmış (European Parliament, 2013) Soysal kararının kapsamına ilişkin belirsizliği ortadan kaldırılması beklenen

7 Case C-16/05 Tum ve Dar1 [2007] ECR I-7415; Case C-228/06, Mehmet Soysal and Ibrahim Savatli v. Bundesrepublik Deutschland [2009] ECR I-1031.

8 Kamyon şoförleri, bazı işçiler, önemli sanatçılar, araştırmacılar ve sporcular. 
Demirkan $^{9}$ davasında ABAD, beklentilerin tersine ${ }^{10}$ Katma Protokolün ilgili hükümlerinin vize açısından hizmet alıcıları kapsamayacağına hükmetmiştir.

2012 yllında en nihayetinde Avrupa Birliği’nin Türkiye’ye vize serbestleştirme teşvikini önermesinde ABAD’ın ardı ardına aldığı kararların etkisi olduğu düşünülmektedir. Ancak Türkiye açısından vizesiz Avrupa için yargısal bir alternatif iyice belirginleşmişken neden 2012 Haziran ayında ABGKA’yı parafladığı açık değildir. Özellikle Türkiye’nin bu kararlardan sonra bir devlet politikası olarak Avrupa ülkelerindeki yerel mahkemelerde benzer davalar açılmasını destekleyerek bu yöndeki yargı kararlarını arttırma yoluna gitmesi ve böylelikle Avrupa Komisyonu ve üye devletler üzerinde hukuki haklarının korunması ve uygulanması için bir baskı yaratması olarak tanımlanabilecek BATNA’nın zaten çok kırılgan olan vize koşulsallığının gücünü iyice zayıflatmış olması beklenirdi. Bu tutum kısmen yargısal müdahalenin Türkiye’ye yönelik vize uygulamasını değiştirmesine karşı AB’nde ortaya çıkan güçlü siyasi direncin Türkiye'deki siyasi aktörlerde yarattığı karamsarlıkla açıklanabilir.

\section{Koşulsallığın Gücü ve Yerel Fırsat Yapısı}

Lavenex ve Uçarer'in göç politikalarına uyuma ilişkin rasyonel karar modeli Türkiye’nin özel şartlarına uygulanması sonucunda ortaya çıkan en önemli soru özellikle verilen sözün tutulması açısından güvenilirliği şüpheli olan vize serbestliği koşulu ile Türkiye’nin kapsamlı bir uyum programının yüksek maliyetlerini neden kabul etmiş olabileceğidir. Koşulsallıktan bağımsız yapılan fayda-maliyet analizleri ile Türkiye açısından net bir sonuca varmak mümkün değildir: modern, tutarlı ve sistemli bir göç politikası oluşturmanın faydalarının karşısında reformların masrafları ile ABGKA’nın maliyetleri konulduğunda AB'ye uyum kararının net bir biçimde ulusal çıkarlara uygun olduğunu, bu nedenle de uyumun isabetli koşulsallı̆ga dönüştüğünü iddia etmek zordur.

Çıkarlar ve değerler açısından müphem bir durumda, uyumsuzluk maliyetlerini arttırarak hesaplamaları değiştirmesi beklenen koşulsallık ise hem güvenilirlik kaybı hem de ABAD kararları nedeni ile erozyona uğramıştır. Ancak bu, vize teşvikinin toplum üzerindeki sosyopsikolojik etkisini ve gücünü yitirdiği anlamına gelmez. Sonuç olarak yukarıdaki rasyonel karar analizi Türkiye’ye özgü koşullarda ulusal çıkar hesaplamalarına dayanarak net bir karar almanın zor olduğuna işaret ettiği için, koşulsallığın gücünü asıl gösterdiği iç siyasi dinamikler ve kamuoyu faktörüne odaklanmak gerekmektedir.

İç politika ve kamuoyu açısından vize koşulsallığı gücünü kısmen Lavenex’in negatif dışsal

924 Eylül 2013, Judgment of the Court (Grand Chamber). Case C-221/11 Leyla Ecem Demirkan v Bundesrepublik Deutschland.

10 Katma Protokolün 41(1) maddesinin kapsamına iş adamları, avukatlar, doktorlar, akademisyenler, öğrenciler, sanatçllar ve aslında iş, turizm, eğitim ve ya tıbbi amaçlı $A B$ ülkelerine seyahat etmek isteyen tüm Türk vatandaşları girmektedir. Prof.Guild'in belirttiği gibi, Ortaklık Anlaşması AB’nin işleyişine dair Antlaşma (eski adı ile Avrupa Topluluğu Anlaşması) ile benzer kurallar rehberliğinde yorumlanmalıdır. 
koşullar adını verdiği Schengen vize alanın yarattı̆̆ı jeopolitik izolasyondan almaktadır (Lavenex ve Schimmelfennig, 2009: 799). Negatif dışsal koşullar özellikle göç alanında kolay şekilde yayılma ve genişleme eğilimindedir. Schengen vize alanının yarattığı izolasyonun önce ODA ülkelerini sonra ise komşuları Batı Balkanları ve ardından da Türkiye’yi etkilemesi bu yayılmacı özelliğin iyi bir örneğidir (Vachudová, 2000).

Negatif dışsal etkiler temelde izolasyona uğrayan ülke halkları tarafından hissedilmektedir. AB vize politikaları Batı Balkanlar'da güçlü bir izolasyon ve dışlanma algısı ile Avrupa'ya yabancılaşma ve aşağılanma etkisi yaratmıştır (Trauner, 2009: 787). Batı Balkanlar ile AB arasındaki vizesiz rejime geçiş süreci ve uygulaması ise aynı etkilerin bu defa Türkiye üzerinde hissedilmesine ve dışlanma ve ayrımcllığa uğrama algısının artmasına yol açtı. AB’nin kendisine uyguladığı katı vize rejimi nedeni ile zaten toplumsal anlamda izolasyonu uzun yıllardır yaşamakta olan Türkiye için bu gelişme Avrupa tarafından ötekileştirilme politikasının (Özler, 2012: 123) somut bir örneği idi. Bu şartlar altında, OGP’nin bir parçası olarak Schengen vize uygulamasının izole edici negatif dış etkileri vize teşviki önerisini Türkiye üzerinde güçlü ve ikna edici bir dış politika aracı haline getirmektedir.

Kısaca vize teşviki esas gücünü $A B$ ’nin Schengen vize sistemi ile komşu ülkelerden izole edilmiş bir Avrupa alanı yaratmasından almaktadır. AB Vize teşvikinin esas hedefi iç politika ve daha da spesifik olarak vatandaşlar ve iç kamuoyudur. $A B$ ile serbest dolaşım hem bireysel hem de ticari anlamda çekicidir. $\mathrm{AB}$ ile kısa-süreli vizelerin kaldırılması hükümetlerin her vatandaşın faydalanabileceği bir kamu faydası sunmasını sağlar. Hükümetin bir politika başarısı olarak iktidar parti ya da partilerine kamuoyu desteğini arttırır. Böylelikle gerek siyasi gerekse ülke çıarları açısından hükümetin fayda-maliyet analizlerini değiştirir. Ek olarak önerilmesinden itibaren iç kamuoyunda hükümete uzlaşması yönünde baskı oluşturması beklenir.

Türkiyede Avrupa Birliği ile ilgili düzenli gerçekleştirilen kamuoyu yoklamalarına bakıldığında $A B$ 'ye üyelik konusundaki desteğin giderek azaldığını, üyeliğe karşı çıkanların oranının ise giderek arttı̆̆ını görmekteyiz. Eurobarometre anketine göre Türkiye’nin AB’ye üyeliği iyi bir şey olur diyenlerin sayısı 2004'de \%71'den 2013'da \%38'e kadar gerilemiştir, kötü bir şey olur diyenlerin oranı ise 2004'deki \%9 değerinden \%37'ye kadar yükselmiştir. Öte yandan koşulsallığın erozyonu kamuoyu araştırma sonuçlarında da yansımalarını bulmaktadır. 2013 yılı verilerine göre toplumun \%65,6’s1 Türkiye’nin AB’ye üye olabileceğini düşünememektedir. (KHU-2013). $\% 76,2$ 'lik bir oran Türkiye’nin $\mathrm{AB}$ üyeliğinin engellendiğini ve \% 44,2'si bunun din ve kültür farklılığı olduğuna inanmaktadır. Yine KHU Araştırmasına göre 'Sizce AB Türkiye'ye karşı güvenilir ve samimi davranıyor mu?' sorusuna verilen hayır cevabı $\% 77,2$ kadar yüksek, Evet ise \%9,0 kadar düşüktür. Türkiye'deki güven düşüşü 2010 'dan beri $\% 30$ 'un altında seyreden güven ve $\% 60$ ve üzerinde seyreden güvensizlik seviyeleri ile Eurobarometre anketlerinde de izlenebilir.

Diğer yandan vizesiz seyahatin AB’nin en önemli getirilerinden biri olacağı düşünülmektedir. Kadir Has 2013 Araştırmasında Sizce AB üyeliği Türkiyeye ne şekilde katkı sağlar? Sorusuna verilen cevaplar arasında serbest dolaşım ve seyahat imkanı oluşur cevabı \%25 ile önemli bir 
seviyededir. Sonuçların yorumunda vizesiz seyahat olasılığının güçlenmesi durumunda olumlu oyların düşüşüne etki edebilecek kadar serbest dolaşım ve seyahat imkanının AB üyeliğine destekte önemli bir rol oynadığının altı çizilmektedir (Açıkmeşe, 2013; KHU, 2013).

Vize konusunun taşıdığı öneme bir gösterge olabilecek ve Eurobarometrede sorulan bir başka soru ise $A B$ size şahsen ne ifade etmektedir sorusudur. 2010'dan itibaren Eurobarometre'nin bu sorusuna verilen cevaplara bakıldığında ekonomik refahtan sonra bir iki istisna dişında $\mathrm{AB}$ içinde herhangi bir yer için seyahat etme, okuma ve çalışma özgürlüğü cevabı genellikle ikinci sırada yer almaktadır. 2013 Güzde ise AB içinde herhangi bir yer için seyahat etme, okuma ve çalışma özgürlüğü seyahat etme \%36 ile Eurobarometre'deki en yüksek seviyesini görmüştür ve ekonomik refah ile birlikte ilk unsur olmuştur. Tablo $1 .^{11}$

\begin{tabular}{|c|c|c|c|c|c|c|c|c|}
\hline Tablo 1 & $\begin{array}{c}\text { EB 73 } \\
\text { bahar } \\
2010\end{array}$ & $\begin{array}{c}\text { EB 74 } \\
\text { güz } \\
2010\end{array}$ & $\begin{array}{c}\text { EB } 75 \\
\text { bahar } \\
2011\end{array}$ & $\begin{array}{c}\text { EB } 76 \\
\text { güz } \\
2011\end{array}$ & $\begin{array}{c}\text { EB } 77 \\
\text { bahar } \\
2012\end{array}$ & $\begin{array}{c}\text { EB 78 } \\
\text { güz } \\
2012 \\
\end{array}$ & $\begin{array}{c}\text { EB } 79 \\
\text { bahar } \\
2013\end{array}$ & $\begin{array}{c}\text { EB } 80 \\
\text { güz } \\
2013\end{array}$ \\
\hline & 2.Sirada & 4.Sirada & 2.Sirada & 2.Sırada & 1.Sirada & 2.Sirada & 3.Sirada & 1.Sirada \\
\hline Barış & $\% 20$ & $\% 16$ & $\% 11$ & $\% 6$ & $\% 16$ & $\% 17$ & $\% 27$ & $\% 24$ \\
\hline Ekonomik refah & $\% 37$ & $\% 35$ & $\% 31$ & $\% 13$ & $\% 23$ & $\% 26$ & $\% 31$ & $\% 36$ \\
\hline Demokrasi & $\% 22$ & $\% 21$ & $\% 20$ & $\% 13$ & $\% 19$ & $\% 18$ & $\% 27$ & $\% 31$ \\
\hline $\begin{array}{l}\text { AB içinde } \\
\text { herhangi bir yer } \\
\text { için seyahat etme, } \\
\text { okuma ve çalışma } \\
\text { özgürlüğü }\end{array}$ & $\% 22$ & $\% 19$ & $\% 25$ & $\% 16$ & $\% 31$ & $\% 23$ & $\% 24$ & $\% 36$ \\
\hline $\begin{array}{l}\text { Dünyada etkin } \\
\text { söz sahibi olma }\end{array}$ & $\% 12$ & $\% 26$ & $\% 21$ & $\% 13$ & $\% 23$ & $\% 17$ & $\% 24$ & $\% 23$ \\
\hline CY & $\% 12$ & $\% 14$ & $\% 18$ & $\% 22$ & $\% 17$ & $\% 15$ & $\% 9$ & $\% 7$ \\
\hline
\end{tabular}

Yukarıdaki kamuoyu yoklamalarının ışığında koşulsallıkta bir sarkaç etkisinden bahsedilebilir. Bir tarafta $\mathrm{AB}$ üyeliğine olan desteğin giderek azalması hükümetin uyum yönünde yapacağı dış politika tercihlerine kamuoyu desteğinin de azaldığını gösterirken, AB hakkında negatif bir imajın kamuoyunda gittikçe yaygınlaşması Türkiye- AB arasındaki işbirliğine karşı çıkışların da artacağını tahmin edebiliriz. AB’ye duyulan güvensizliğin şiddeti ve yaygınlığı ise üyelik ya da vizesiz seyahat gibi $A B$ koşulsallıklarını önemli oranda zayıflatan bir faktördür- çünkü AB’nin verdiği sözleri yerine getirmesi ile ilgili yaygın bir toplumsal kuşku vardır.

Öte yandan vize meselesinin tüm bu koşullar altında bile birkaç nedenle bir istisna teşkil ettiği iddia edilebilir. İlki vizesiz seyahat teşvikinin kendi başına toplumun birçok kesimi için cazibesidir. $\mathrm{Bu}$ cazibe serbest dolaşımın $\mathrm{AB}$ üyeliğinin en önemli faydalarından biri olarak algılanmasında

11 Yer darlığından belirtilemeyen diğer seçenekler, Sosyal güvenlik, Kültürel Çeşitlilik, Euro, İşsizlik, Bürokrasi, Para israfı, Kültürel kimliğimizin kaybolması, Daha fazla suç, Dış sınır bölgelerinde yetersiz kontrol, ve Diğer. 
açıkça görülebilir. Diğer neden ise, Vize Şikayet Hattı Projesinin ortaya koyduğu gibi, Sırbistan, Karadağ ve Makedonya vatandaşlarına çok kısa bir süreç sonunda vize muafiyeti hakkını tanıyan Birliğin, söz konusu imkânı neredeyse yarım asırdır AB ile ortaklık ilişkisi içerisinde bulunan ülkemiz vatandaşlarına tanımamasının yarattığı rahatsızlıktır. Türkiye’ye ve Türklere yönelik ayrımcı uygulamalarının devamı gibi algılanmaktadır. Bu durum 'Türk toplumunda, bu alanda AB ile ilişkisi bizim kadar ileri olmayan ülke vatandaşlarına kıyasla, ayrımcılık ve sadece insani bir hakkın ihlali anlamında haksızlıklarla karsı karsıya olunduğu algısına yol açmaktadır' (Özer ve Özsöz, 2010: 4). ${ }^{12}$

Kısaca vize teşviki karşılığında göç politikalarına uyum müzakerelerinde koşulsallığın kamuoyu ve dolayısı ile hükümet üzerindeki sarkaç etkisi; bir yanda toplumda yaygın şekilde AB ile ilgili karamsarlık, güvensizlik ve olumsuz imaj gibi duyguların işbirliğine karşı yarattığı işbirliğinden çekinme etkisine karşılık vizesiz seyahat için yaygın talep ve ayrımcılığın bitirilmesi isteğinin yarattığı işbirliğine itme etkisi olarak tanımlanabilir. İtme etkisinin hükümet üzerindeki gücünü arttıracak önemli unsurlardan biri ise farklı kamuoyu araştırmaları tarafından ortaya konan, AB destekleyenler arasında AKP seçmen oranının diğer partilere göre en yüksek oranda olmasıdır. ${ }^{13}$ Aşağıda bu iç politika koşulları altında hükümetin müzakereler boyunca izlediği strateji analiz edilmektedir. Bir başka Türkiye’ye özgü koşul olan BATNA’nın koşulsallık ve dolayısı ile dış politika kararları üzerindeki, süreç içinde gelişmelere göre artan ve azalan, etkisi de ayrıca izlenecektir.

\section{Hükümetin İzlediği Strateji}

Türkiye hükümeti GKA ile vize meselesinin eşleştirilmesi ile ilgili talebini ilk kez 2009'da ifade etmiş, 2010'daki Ortaklık Konseyi toplantısında Türkiye’nin ABGKA’yı imzalaması vizesiz Avrupa teşvikine açıkça bağlansa da vize kolaylaştırma diyaloguna başlamak isteyen Avrupa Komisyonu'na Konsey yetki vermemiştir. Şubat 2011'de Anlaşma taslağı üzerinde Türkiye ile uzlaşmaya varıldığını ilan eden AB’nin karşısında Mayıs 2011'de Türkiye Dışişleri Bakanı ABGKA’nın paraflanmasının vize kolaylaştırma ile değil vize serbestleştirme için Avrupa Komisyon'unun yetkilendirilmesi halinde mümkün olacağını (Groenendijk ve Guild 2011: 5860) ve Türkiye’nin ikinci sınıf bir ülke olmadığını, her medeni ulus gibi eşit muamele beklediğini

122009 ve 2010 yıllarında TOBB’un desteği ile IKV ve sivil toplum örgütü European Citizen Action Service (ECAS) tarafından gerçekleștirilen Vize Şikayet Hattı projesi farklı çevrelerden vize kurbanlarının gerçek hayat hikayeleri ile vize probleminin doğasını ve kapsamını belgeleyen ilk sivil inisiyatiftir.

13 Özellikle muhafazakar kesimin (1lımlı muhafazakar ve muhafazakar/dindar) AB üyeliğini desteklediği hususu Kadir Has Üniversitesi’nin düzenlediği kamuoyu yoklamasında da öne çıkmıştır. Ayrıca Ekonomi ve Dış Politika Araştırmalar Merkezi tarafından (Türkiye’de Dış Politika ve Kamuoyu Anketleri 2013/1) 'Bu yıl Türkiye ile Avrupa Birliği arasında imzalanan Ankara Antlaşmasının 50. yılı. Türkiye’nin tam üyelik müzakerelerinin de 8. yılı. Sizce, önümüzdeki 5 yılda Türkiye şimdi okuyacaklarımdan hangisini yapmalı?” sorusu yöneltilmiştir Özellikle “tam üyelik hedefinde ısrarlı” olunması görüşünde olanlar AKP seçmenlerinin \% 34’ünü oluşturmaktadır. CHP seçmenlerinin \%26’sı ve AKP seçmenlerinin \%21,5’u yeni bir tür ilişki kurulmasını savunmaktadır. Kısaca AKP seçmenlerinin \% 56 ’lık bir kesiminin $\mathrm{AB}$ ile ilişkilerin geliştirilmesini ve işbirliğini desteklediği sonunca varılabilir. 
açıklamıştır ifade etmiştir (Davutoğlu, Twitter, 2011).

Kısaca 2009 yılından itibaren Türk kamuoyu açısından vize meselesinin çerçevesini (Levy, 1997: 90-91) GKA imzalanması karşılığında AB’nin vize serbestleştirme teşvikini Türkiye’ye de önermesi ve böylece açıç̧a devam eden ayrımcı muamelenin sona erdirilmesi oluşturmuştur. Böyle bir çerçeveleme $^{14}$ tam da kamuoyunda yukarıda ayrıntılı tartışılan hakim duyguların dış politikadaki ifadesi gibi görünmektedir ve iki önemli gelişme tarafından güçlendirilmiştir. Bunlardan ilki Kasım 2009'da Sırbistan, Karadağ ve Makedonya için AB’nin vizesiz seyahat kararını almış olmasıdır. Diğer konu ise 2007'deki karardan sonra, 2009 Şubat ayında ABAD’ın Soysal kararını açıklamasıdır. Kararın AB tarafından nasıl uygulanacağını bekleyen Türkiye Komisyon'un Kasım 2009'da yayınlanan sadece birkaç ülke için aldığı tavsiye niteliğindeki karardan sonra ABGKA müzakerelerinde uzlaşma için vize muafiyetini ön şart olarak koymuştur.

Böylelikle Haziran 2012'de nihayet AB vize serbestleşme önerisini Türkiye’ye sunduğunda Türkiye'nin ABGKA’yı paraflaması bu “mesele çerçevesinin”, Türkiye için dış politika tercihlerini, ABGKA’yı kabul etme ya da reddetme seçeneklerine indirgemiş olduğunu göstermektedir. Burada AB’nin yargı kararlarını uygulayışına dair ümitsizlik ve karamsarlığın önemli rol oynadığını görmekteyiz. Nitekim neden ABGKA’yı paraflamayı seçtiklerini açıklarken AB Bakanı Egemen Bağış 'yargı kararları ile sağlanan gelişmeler uzun zaman aldığından ve üye devletler arasında uygulamada farklılıklara da yol açabildiğinden’ şikayet etmiş ve yargı kararlarının vize çilesini sona erdirmediğini vurgulamıştır. 'Uluslararası alanda hukuken haklı olmanın her zaman sonuç almaya yetmediğinin’ altını çizmiştir (Cnnturk.com, 2012).

Bir türlü Türkiye'ye karşı standart uygulamaları gerçekleştiremeyen AB, en nihayetinde iç dinamiklerden kaynaklanan siyasi kaygıları yenerek normalde sunması gerekeni önerdiğinde ABGKA’nın paraflanmasının -AB’nin uzun süredir devam ettirdiği ayrımcı uygulamanın sona erdirilmesi ve Türk vatandaşlarının vizesiz Avrupa beklentilerini karşılaması anlamında- Türk kamuoyunda bir başarı gibi algılanması ve hükümet tarafından bu şekilde sunulması kaçınılmaz gibi görünmektedir (Hurriyet.com.tr, 2012). Böylece mesele çerçevelemesi bir tercihin kayıp mı kazanç mı olarak algılanacağını baştan belirlemişti (Tversky ve Kahneman, 1986).

Ancak koşulsallığın Türkiye’ye özgü koşullar nedeni ile bir sarkaç etkisi yarattığı göz önüne alındığında bu kararın başka siyasi maliyetler yaratma potansiyelini unutmamak gerekir. Nitekim ABAD kararlarına ve yüksek güvensizliğe rağmen bu tür bir anlaşmaya imza atılması Türkiye'nin AB’ye yine gereksiz bir taviz vermesi olarak eleştirilmiştir. Nitekim kamuoyu gözünde koşulsallığın erozyonu hükümetin paraflamadan sonraki stratejisine 'şartlı kabul' seçeneğini olarak yansımıştır. Şartlı kabul seçeneği koşulsallık kredibilitesinin zayıflı̆̆ı nedeni ile yüksek riskli ve maliyetli bir tercihte risk unsurunu azaltmaya yönelik bir strateji ve kamuoyu gözünde negatif bir imaja sahip AB’ye yine belirsiz bir taahhüt karşısında tavizler verildiği suçlamasını bertaraf edebilecek bir ara seçenekti.

14 Referans noktasının belirlenmesi ve ya çerçeveleme tercih üzerinde kritik bir etkiye sahiptir. Çerçevede bir değişiklik tercihlerde bir değişikliğe neden olabilir. 
Örneğin Türkiye ABGKA’yı paraflamasına rağmen, imza için vize serbestleştirme yol haritasının açıklanmasını beklemiştir. Paraflama kararının kamuoyu ile paylaşımı ise benimsenen aynen karşlık (tit-for-tat) stratejisi vurgulanarak gerçekleştirildi: Vize muafiyeti eylem planı önerilince ABGKA imzalanacak, eylem planının uygulamaya geçilmesi ve ilerleme sağlanmasıyla birlikte Türkiye, ABGKA'yı onaylayacak ve 'vize muafiyeti' aşamasına gelindiğinde uygulamaya başlayacaktı (Lüle, hürriyet.com.tr, 2012; Ergan, hürriyet.com.tr, 2012; Zeyrek, radikal.com.tr, 2012). AB Aralık 2012'de yol haritası açıklandığında -ki belgeyi AB ya da Türkiye resmi olarak kamuyla paylaşmamıştır- yankıları büyük oldu (milliyet.com.tr, 2012). Türkiye’nin aynen karşılık stratejisi ve şartlı kabul seçeneği başarısızlığa uğramıştı. Yol haritasına göre diğer ülkelerle olduğu gibi Türkiye ile de performansa dayalı ve koşullu bir vize serbestleştirme süreci öngörülüyordu. ABGKA’nın imzalanması dahil olmak üzere uzun bir yükümlülükler listesi vardı ve bu şartlar Türkiye tarafından etkin ve tutarlı uygulandığında vize serbestleştirmeye geçilebilirdi. Ayrıca belgede birçok kereler vize serbestleştirme sürecinin 'uzun-dönem’e yayılacağı ibaresi kullanılmıştı (Council of the European Union, 2012).

Bir anlamda koşulsallık sarkacı diğer yönü göstermiş ve sonuçta müzakereler tekrar bir yll süre ile tıkanmıştır (TC Dışişleri Bakanlığı, 2012; haberpan.com, 2012). Türkiye’nin süreci yavaşlatmasında, şartlı kabul taktiğinin başarısızlığı kadar, Demirkan davasının 2013 yılı içinde sonuçlanmasını beklenmesi de rol oynamış olabilir. Ancak 2013 Eylül'ünde ABAD Demirkan davasında Katma Protokolün ilgili hükümlerinin vize açısından hizmet alıcıları kapsamayacağına hükmetmiştir. Bu kararın BATNA konusundaki son ümitleri de kırdığı düşünülebilir.

Nihayetinde Türkiye’nin meşruhatlı bir yol haritası hazırlanması yönünde sürdürdüğü pazarlıkların sonuçlandığı açıklanmış ve 16 Aralık 2013'de Türkiye ve ABGKA'yı imzalamıştır. Dışişleri Bakanlığı’nın yeni yol haritasında Türkiye’nin hassasiyetlerine özen gösterildiğini sürekli vurgulamasına rağmen yol haritasındaki bazı noktalar kamuoyu nezdinde AB’nin güvenilirliğini iyice zedeleyerek ilişkilere zarar verebilecek bir süreç ihtimalini düşündürmektedir (Eralp, 2013). Yol Haritasına göre Türkiye’nin coğrafi sınırlamayı kaldırması, yasa dışı mültecilerin geldiği ülkeler ve $A B$ 'ye göç ve güvenlik açısından risk taşıyan ülkelere karşı vize politikalarını değiştirmesi beklenirken; reformlar için $A B$ ’nin sağlayacağı mali yardım konusunun belirsiz bırakılmıştır. $A B$ Bakanlığı ise hazırladığı rehber kitapçıkta (AB Bakanlığı, 2013) ilk iki koşulun Türkiye’nin AB'ye üye olurken yerine getirilebileceğini ifade etmektedir. Medyaya yansıyan açılamalar muafiyetin anlaşmanın imzalanmasından 3-3,5 yıl sonra ve otomatik olarak yanılgısını yaratırken, yol haritasına göre muafiyet kararının alınabilmesi için şart olan üçüncü ülke vatandaşlarının geri kabulüne Türkiye Anlaşma yürürlüğe girdikten üç yll sonra başlayacaktır.

\section{AB Koşulsalık Erozyonunun Sonuçları: Sarkaç Etkisi ve Güvensizlik Sarmalı}

Burada makalenin teorik argümanlarından yola çıkılarak sorulabilecek önemli bir soru vardır. Eğer politika-yapıcılar öncelikle iç politika izleyici maliyetlerini hesaba katarak dış politika stratejilerini belirliyorlarsa neden AB’nin verdiği sözleri tutmayacağına dair güçlü şüpheler ve 
emareler varken kapsamlı bir reform listesine altına imza atarak ilerde seçmenler tarafından bu tercih nedeni ile cezalandırılma riskini almışlarıdır? Bunun cevabı aslında yine döngüsel biçimde koşulsallık erozyonunda yatmaktadır. Koşullu kabulün bir strateji olarak uzlaşıya varma açısından başarılı olamaması ve ya en nihayetinde sürecin kamuoyunun vize serbestisi beklentisini karşılayamaması hükümete bir siyasi maliyet olarak geri dönmemektedir çünkü ayrımcılık yapan Avrupa imajına uygun biçimde AB’nin çeşitli bahanelerle verdiği sözleri tutmamasının bir başka somut örneği olarak algılanmaktadır (İçduygu, 2011). ${ }^{15}$. Uzun vadede uzlaşma ve işbirliği sürdürülemediği için bir kazanç elde edilemese bile kısa vadede belli taahhütlerin karşılıklı alışverişi aslında AB-Türkiye ilişkilerinde tekrarlanan bir şablon gibi görünmektedir.

Yukarıdaki analizler ışı̆̆ında hem bir güvensizlik stratejisinden hem de bir güvensizlik kısırdöngüsünden bahsedilebilir. AB kendi kamuoyunun baskısı ile Türkiye söz konusu olduğunda standart ve objektif uygulamaların dışında hareket etmekte, normal prosedürler istisnalarla ve gecikmeli uygulanmakta, diğer ülkelere gösterilen esnekliğin yerini negatif Türkiye imajı nedeni ile çok daha sert uygulanan kriterler ve yaptırımlar almaktadır. AB’nin istikrarsız yaklaşımı ve isteksizliği bir yandan AB ile ilgili yerleşmiş standartların Türkiye’ye de uygulanması anlamında her 'normalleşmeyi' bir dış politika başarısı haline getirirken diğer yandan Türk kamuoyundaki güvensizliği arttırıp reformlar ile uyum çabalarına verilen desteği kırılganlaştırarak ve fayda maliyet hesaplarında AB koşulsallığını belirsizleştirip zayıflatarak, iç politika izleyici maliyetlerini almak istemeyen Türkiye'deki siyasetçilerin uyum yükümlülüklerini sonuna kadar ve tam anlamı ile yerine getirmesini gitgide zorlaştırmaktadır (Rumelili, 2007). ${ }^{16}$

Her iki tarafın ilişkilerdeki güvensizliğge ${ }^{17}$ güvenerek karşılıklı taahhütler içine girmesi ise güvensizlik stratejisine dalalet eder. Güvensizlik stratejisi kısaca Türkiye’nin belirli bir işbirliği alanındaki sürecin bir noktada AB’nin objektiflikten uzak siyasi yaklaşımı ve kamuoyu karşıtlı̆̆ı nedeni ile tıkanacağını bildiği için aslında uzun vadede uyum maliyetlerinin tamamını üstlenmek; AB’nin ise uzun vadede taahhüdünü yerine getirmek ve böylece iç politika izleyici maliyetlerini üstlenmek zorunda kalmayacağına güvenerek hareket etmesi olarak tanımlanabilir.

15 Ahmet İçduygu göç alanındaki pazarlıkların başarısızlığı halinde durumun bir 'karşılıklı suçlama' oyununa dönüşebileceğini belirtmektedir.

16 Bahar Rumelili’nin AB-Türkiye ilişkilerini kimlik ve inşacı söylem üzerinden değerlendirirken 90 'lı yllar için bahsettiği 'kısır döngü' sona ermemiş gibidir.

17 Uluslararası ilişkiler de güven ve güvensizlik kavramının analizlere dahil edilmesi 1950'lere kadar uzanmaktadır (Deutsch, 1958). Uluslararası ilişkilerde "güven"i diğerinin ya da diğerlerinin doğru olan şeyi yapacağına dair duyulan inanç temelinde onların gelecekteki davranışlarına ilişkin risk almayı istemek ya da bu riski almaya razı olmak olarak tanımlayan Hofffman’n makalesi özellikle dikkat çekicidir (Hoffman, 2002). Bu anlamda Türkiye - AB arasındaki ilişkide hakim olanın bu tür bir inancın yokluğu ya da azlığı temelinde aslında riskli olacak politikaları realize etmekten kaçınmak olduğu iddia edilebilir. Ayrıca vatandaşların kendi uluslarının diğer uluslara/ülkelere ne kadar güvenebileceklerine dair genelleştirilmiş bir inanç olarak "uluslararası güven" üzerine yapılan çalışmalar güven/güvensizlik kavramını siyasi aktörlerin ötesinde kamuoyunu kapsayacak şekilde genişletmektedir (Brewer vs., 2004.) 


\section{Sonuç}

Bu makalede Geri Kabul Anlaşması konusunda Türkiye’nin değişen tercihini anlamaya çalışırken Türkiye-AB ilişkilerinde karar alma süreçlerini açıklamada Lavenex ve Uçarer’in ortaya koyduğu Avrupalılaşma modeli test edilmeye çalışılmıştır. Özellikle modelin yerel fırsat yapısının rolüne işaret etmesi nedeniyle Avrupa Birliği ile ortaklık ve işbirliğine bakışı belirleyebilecek toplumsal algı ve tutumlar da göz önüne alınarak, kamuoyu desteğini gözeten politika-yapıcıların dikkate almış olabileceği iç politika dinamiklerine ilişkin bazı değerlendirmeler yapılmıştır.

Makalenin geliştirilmiş bir kuramsal çerçeve ile yaptığı analizlerle vardığı sonuçlar aşağıdaki gibi özetlenebilir. Türkiye’nin 2013 Aralık ayında ABGKA’yı imzalamasına kadar izlediği dış politika gerek sürecin kesintilere sık sık uğramasından gerekse müzakerelerin kamuoyuna sunum şeklinden anlaşıldığı kadarı ile dalgalı bir seyir izlemiştir. Bu değişken ve bir noktaya kadar temkinli diş politika sürecinin karar almada rasyonel bir fayda-maliyet analizinden çok bir yandan iki çelişen toplumsal talebe aynı anda karşılık vermeye çalışan bir yandan ise müzakerelerde sunulan teşvike alternatif teşkil edebilecek yargı kararlarının neticelerini takip eden karar-alıcıların iç siyasetteki izleyici maliyetlerinden kaçınma çabasından kaynaklandığı düşünülebilir. Kamuoyunda bir yandan AB’ye üyelik için verilen destek önemli ölçüde düşmüş ve güvensizlik ciddi boyutlara ulaşmıştır; diğer yandan AB'nin ayrımcı uygulamalarından biri olarak görülen vize uygulamasını sona erdirecek ve AB'ye vizesiz seyahati sağlayacak bir politika toplumda ciddi anlamda destek bulacaktır. Vize koşulsallığı bu anlamda kamuoyunda hem bir işbirliğine itme hem de taviz verecek pozisyonlardan çekinme etkisini aynı anda yaratmaktadır. Koşulsallığın uyum kararlarındaki sarkaç etkisi olarak adlandırdığımız bu durum reformların ve uyum çabalarının istikrarını da tehdit eder niteliktedir. İkili ilişkiler açısından daha da önemli bir sonuç ise koşulsallık sarkacının karşılıklı güvensizliği giderek arttığı bir güvensizlik sarmalı yaratmasıdır. Yukarıdaki analizler ABGKA müzakerelerinin bu sarmaldan etkilenme ve bu sarmalı kuvvetlendirme potansiyeli olduğunu ortaya koymaktadır. 


\section{Kaynakça}

AB Bakanlığı (Aralık 2013) Türkiye-AB Vize Muafiyeti Süreci ve Geri Kabul Anlaşması Hakkında Temel Sorular ve Yanitları, http://www.ab.gov.tr/files/pub/vize_gka_kitap_15_12_2013.pdf /23.03.2015

Açıkmese, S. A. (2010) "Cycles of Europeanization In Turkey: The Domestic Impact of EU Political Conditionality", UNISCI Discussion Papers, no 23.

Aydin, U., K. Kirişci (2013) "With or Without the EU: Europeanisation of Asylum and Competition Policies in Turkey". South European Society and Politics, 18(3): 375-395.

Apap, S. C., K. Kiriş̧̧i (2004) “Turkey in the European Area of Freedom, Security and Justice”, CEPS EUTurkey Working Papers, no 3, Brussels.

ATAUM (2010) Kamuoyu ve Türk Dış Politikası Anketi, ataum.ankara.edu.tr/anket.pdf / 23.03.2015.

Avc1, G. (2011) “The Justice and Development Party and the EU: Political Pragmatism in a Changing Environment”, South European Society and Politics, 16 (3): 409-421.

Avrupa Konseyi Parlamenter Meclisi (2010) "Geri kabul düzenlemeleri: düzensiz göçmenlerin geri gönderilmesine yönelik bir mekanizma”, Göç, Mülteciler ve Nüfus Komitesi Raporu, Doc. 12168.

Avrupa Mülteciler ve Sürgünler Konseyi (ECRE) (2007). Defending Refugees' Access to Protection in Europe, www.ecre.org/component/downloads/downloads/60.html/ 23.03.2015.

Bauer, M. W., C. Knill, and D. Pitschel (2007) “Differential Europeanization in Eastern Europe: The Impact of Diverse EU Regulatory Governance Patterns”. Journal of European Integration, 29 (4): 405-423.

Billet, C. (2010) “EC Readmission Agreements: A Prime Instrument of the External Dimension of the EU’s Fight against Irregular Immigration. An Assessment after Ten Years of Practice”, European Journal of Migration and Law, 12(1): 45-79.

Boswell, C. (2003) “The External Dimension of EU Immigration and Asylum Policy”. International Affairs, 79(3): 619-638.

Bouteillet-Paquet, D. (2003) "Passing the Buck: A Critical Analysis of the Readmission Policy Implemented by the European Union and Its Member States" European Journal of Migration and Law, 5 (3): 359-377.

Brewer, P. R., K. Gross, S. Aday, and L. Willnat (2004) “International Trust and Public Opinion about World Affairs", American Journal of Political Science, 48(1): 93-109.

Bürgin, A. (2012) “European Commission’s Agency Meets Ankara’s Agenda: Why Turkey is Ready for a Readmission Agreeement", Journal of European Public Policy, 19(6): 883-899.

Case C-16/05 Tum ve Dar1 [2007] ECR I-7415.

Case C-221/11 Demirkan, OJ C 232, 06.08.2011, 15.

Case C-228/06 Mehmet Soysal and Ibrahim Savatli v. Bundesrepublik Deutschland [2009] ECR I-1031.

Case C-221/11 Leyla Ecem Demirkan v Bundesrepublik Deutschland, 24 Eylül 2013, ABAD kararı.

Council of the European Union (2011) Council Conclusions on EU-Turkey Readmission Agreement and Related Issues, 3071, Adalet ve İçişleri Konseyi Toplantısı, Brüksel, 24 ve 25 Şubat 2011.

Council of the European Union (2012a) Council Conclusions on Developing Cooperation with Turkey in the Areas of Justice and Home Affairs, 3177th Employment, Social Policy, Health and Consumer Affairs Council Meeting, Luxembourg, 21 june 2012.

Council of the European Union (2012b) Broader Diologue and Cooperation Framework on Justice and Home Affairs: Roadmap towards a Visa-Free Regime, 17347/12 Limite, Enlrg 128, JAI 881, 6 december 2012, Brussels.

Council Regulation (EC) No 539/2001, 15 march 2001, listing the third countries whose nationals must be in possession of visas when crossing the external borders and those whose nationals are exempt from that requirement. 
Deutsch, M. (1958) “Trust and Suspicion”, Journal of Conflict Resolution, 2: 265-279.

Düvell, F. (2013) "Turkey, the Syrian Refugee Crisis and the Changing Dynamics of Transit Migration", IEMed Mediterranean Yearbook, Barcelona: IEMed, 278-281.

Ekonomi ve Dış Politika Araştırmalar Merkezi (2013) Türkiye’de Dış Politika ve Kamuoyu Anketleri (2013/1), edam.org.tr/document/EDAMAnketOcak2013.pdf / 23.03.2015.

Eralp, N. A. (Aralık 2013) “AB ülkeleri Türkiye’ye vize uygulamasını kaldırıyor mu?”, TEPAV Değerlendirme notu.

Eser, R., D. Toigonbaeva, (2011) “Psikoloji ve İktisadın Birleşimi Olarak Davranışsal İktisat”, Eskişehir Osmangazi Üniversitesi İIBF Dergisi, 6(1): 287-321.

Euro-mediterranean Human Rights Network (2013) "An EU-Turkey Readmission Agreement-Undermining the rights of Migrants, Refugees and Asylum Seekers?", Policy Brief, http://www.euromedrights. org/eng/2013/06/20/an-eu-turkey-readmission-agreement-undermining-the-rights-of-migrantsrefugees-and-asylum-seekers/ 23.03.2015.

European Commission (2010-2013) Standard Eurobarometer (73-80), http://ec.europa.eu/public_opinion/ archives/eb_arch_en.htm / 30.03.2015.

European Commission (2011) Proposal for a Regulation amending Council Regulation (EC) No 539/2001, $\operatorname{COM}(2011)$, 290, final 2011/0138 (COD), 24.5.2011.

European Commission (2009) "Guidelines on the Movement of Turkish Nationals Crossing the External Borders of EU Member States in Order to Provide Services within the EU", Commission Recommendation, 29.9.2009, (C (2006) 5186 final).

European Commission (2012) Commission Recommendation, C(2012) 9330 final, Brussels, 14.12.2012.

European Parliament (2011) Committee on Civil Liberties, Justice and Home Affairs, 2011/0138(COD), 7.12.2011, AMENDMENTS 13 - 54, Draft Report: Agustín Díaz de Mera García Consuegra, http:// www.europarl.europa.eu/oeil/popups/ficheprocedure.do?id=591721\#externalLinks / 23.03.2015.

European Parliament (2013) Report on the proposal for a regulation of the European Parliament and of the Council amending Council Regulation,(EC) No 539/2001 A7-0139/2013, 19 april 2013.

Groenendijk, K., E. Guild, (2011) Visa Policy of Member States and the EU towards Turkish Nationals After Soysal, IKV Yayınları, No 249.

Güney, A., A. Tekin (2016) The Europeanization of Turkish Public Policy: A Scorecard, New York: Routledge.

Hix, S., K. H. Goetz (2000) Europeanised Politics? European Integration and National Political Systems, London: Frank Cass Publishers.

Hoffman, A. M. (2002) "A Conceptualization of Trust in International Relations", European Journal of International Relations, 8(3): 375-401.

Human Rights Watch (2006) European Union: Managing Migration Means Potential EU Complicity in Neighboring States' Abuse of Migrants and Refugees, http://www.hrw.org/legacy/backgrounder/eca/ eu1006/23.03.2015

İçduygu, A. (January, 2011) “Europe, Turkey, and International Migration: An Uneasy Negotiation”, Paper presented at the Migration Working Group, Florence: European University Institute (EUI).

İçduygu, A. (2011) "The Irregular Migration Corridor between the EU and Turkey: Is it Possible to Block it with a Readmission Agreement?", Florence: European University Institute (EUI). EU-US Immigration Systems Papers, 2011/14.

İnsan Hakları Araştırmaları Derneği (2013) Türkiye İltica Hakkı İzleme Raporu, Ankara.

Kadir Has Üniversitesi (2013) Türk Dış Politikası Kamuoyu Algıları Araştırması: Kantitatif Araştırma Raporu, İstanbul.

Karayigit, M. T. (2011) "Vive la Clause de Standstill: The Issue of First Admission of Turkish Nationals into the Territory of a Member State within the Context of Economic Freedoms", European Journal of 
Migration and Law, 13(4): 411-441.

Kirişçi, K. (2005) “A Friendlier Schengen Visa System as a Tool of "Soft Power”: The Experience of Turkey", European Journal of Migration and Law, 7( 5): 343-367.

Kirişçi, K. (2007) “Yumuşak Güç” Aracı Olarak Daha Dostça Bir Şengen Vize Sistemi: Türkiye’nin Deneyimi”, Uluslararası İlişkiler, 4(13): 27-56.

Kirişçi, K. (2009) "Harmonisation of Migration Policy and Turkey's Security Challenges", Centre for Economics and Foreign Policy Studies (CEPS) Discussion Paper Series, 2009 / 01.

Kirişçi, K. (2012) “Turkey’s New Draft Law on Asylum: What to Make of It?” in Pacaci Elitok H. S. and T. Straubhaar, Turkey, Migration and the EU: Potentials, Challenges and Opportunities, Hamburg: Hamburg University Press, 63-85.

Kruse, I. (September, 2003) "Creating Europe Outside Europe: Externalities of the EU Migration Regime", Paper presented at the ECPR Conference, Marburg.

Lavenex, S. (2001) "Migration and the EU's New Eastern Border: Between Realism and Liberalism”, Journal of European Public Policy, 8(1): 24-42.

Lavenex, S., E. M. Uçarer (2004) “The External Dimension of Europeanization: The Case of Immigration Policies", Cooperation and Conflict, 39(4): 417-443.

Lavenex, S. (2006) "Shifting up and out: The Foreign Policy of European Immigration Control", West European Politics, 2 (29): 329-350.

Lavenex, S. ve F. Schimmelfennig (2009). "EU Rules beyond EU Borders: Theorizing External Governance in European Politics", Journal of European Public Policy, 16 (6): 791-812.

Lavenex, S. (2011) “Concentric Circles of Flexible 'EUropean' Integration: A Typology of EU External Governance Relations", Comparative European Politics, 9 (4): 372-393.

Levy, J. S. (1997) "Prospect Theory, Rational Choice and International Relations", International Studies Quarterly, 41 (1): 87-112.

March, J. G., J. P. Olsen (1989) Rediscovering Institutions: The Organizational Basis of Politics, New York: Free Press.

Özler, Z., M. Özsöz (2010) Vize Şikayet Hattı Proje Raporu, İstanbul: İKV Yayınları, No 227.

Özler, Z. (2012) “Breaking the Vicious Circle In the EU-Turkey Relations: Visa Negotiations”, Turkish Studies Quarterly, 11(1): 121-131.

Özsöz, M. (Mart, 2013) “Türkiye’nin AB Üye Ülke Vatandaşlarına Uyguladığı Vize Politikası”, İKV Değerlendirme Notu, No.66.

Roig, A., T. Huddleston (2007) "EC Readmission Agreements: A Re-evaluation of the Political Impasse", European Journal of Migration and Law, 9(3): 363-387.

Rumelili, B. (2007) Constructing Regional Community and Order in Europe and Southeast Asia, New York: Palgrave Macmillan.

Schimmelfennig, F. (2012) “Europeanization Beyond Europe”, Living Reviews in European Governance, 7(1), http://www.livingreviews.org/ireg-2012-1/11 january 2013.

Sedelmeier, U. (2011) "Europeanisation in New Member and Candidate States", Living Reviews in European Governance, 6(1), http://www.livingreviews.org/lreg-2011-1/11 january 2013.

Soyaltın, D. (2013) “Good news, Bad News or No News: Management of Irregular Migration in Turkey", Research Turkey, II (3): 33-45

Tekin, A., A. Güney (2015) The Europeanization of Turkey: Polity and Politics, New York: Routledge.

Tezcan, N., P. J. Slot (2010) "Free Movement of Persons Between Turkey And The EU”, Cleer Working Papers 2010/2, Centre for the Law of EU External Relations,.

Toksöz, G., S. Erdoğdu, S. Kaşka (2012) Türkiye’de Düzensiz Emek Göçü ve Göçmenlerin İsgücü Piyasasındaki Durumları, IOM. 
Tolay, J. (2012) “Turkey’s “Critical Europeanization”: Evidence from Turkey’s Immigration Policies” in Pacaci Elitok, H. S., T. Straubhaar, Turkey, Migration and the EU: Potentials, Challenges and Opportunies, Hamburg: Hamburg University Press, 39-62.

Trauner, F., I. Kruse (2008) "EC Visa Facilitation and Readmission Agreements: Implementing a New EU Security Approach in the Neighbourhood", CEPS Working Document, Brussels, no 290.

Trauner, F., I. Kruse (2008) "EC Visa Facilitation and Readmission Agreements: A New Standard EU Foreign Policy Tool?", European Journal of Migration and Law, 10 (4): 411-438.

Trauner, F. (2009) "From Membership Conditionality to Policy Conditionality: EU External Governance in South Eastern Europe", Journal of European Public Policy, 16(5): 774- 790.

Tversky, A., D. Kahneman (1986) "Rational Choice and the Framing of Decisions", Journal of Business, 59 (4): 251-278.

Uluslararas1 Af Örgütü (April 2012) Stranded Refugees in Turkey Denied Protection.

UTSAM (2012), Küresel Göç ve Fırsatçıları: Türkiye’de Yasadışı Göçmenler ve Göçmen Kaçakçıları, UTSAM Raporları Serisi, 18 Mayıs 2012.

Vachudová, M. A. (2000) "Eastern Europe as Gatekeeper: The Immigration and Asylum Policies of an Enlarging European Union" in Peter A., T. Snyder (eds.), The Wall Around the West: State Borders and Immigration Control in North America and Europe, Rowman and Littlefield.

Vukašinović J. (2011) "Illegal Migration in Turkey-EU Relations: An Issue of Political Bargaining or Political Cooperation?", European Perspectives, vol. 3, 2(5): 147-166.

\section{Gazete ve İnternet Haberleri}

“79 adım at vizeyi kap!”, Milliyet, 14 Aralık 2012, http://dunya.milliyet.com.tr/79-adim-at-vizeyi-kap-/ dunya/dunyadetay/14.12.2012/1641555/default.htm [Erişim tarihi 12 Ocak 2012].

“AB-Türkiye Geri Kabul Anlaşması’nın Gölgesinde 18 Aralık Dünya Göçmenler Günü”, 19 Aralık 2013, http://www.multecihaklari.org/.

Açıkmeşe, S. A., "Kamuoyu AB Üyeliği konusunda umutlu”, Milliyet, 13.12.2013.

"Bağış: Vizesiz Avrupa’ya vize çıktı”, Hürriyet, 21 Haziran 2012, http://www.hurriyet.com.tr/planet/20810110. asp [Erişim tarihi 12 Ocak 2013].

Davutoğlu, A., Twitter, 25 Şubat 2011, http://twitter.com/\#!/ahmet_Davutoglu.

"Egemen Bağış: Hedef Schengen ülkelerine vizesiz giriş", 28.12.2012, cnnturk.com.

Ergan, U., "Vizesiz AB için tarihi paraf", Hürriyet, 21 Haziran 2012, http://www.hurriyet.com.tr/ planet/20807479.asp, [Erişim tarihi 10 Aralık 2012].

Lüle, Z., "Vize serbestisine Rum müdahalesi”, 22 Haziran 2012, Hürriyet, http://www.hurriyet.com.tr/ planet/20812002.asp, [Erişim tarihi 18 Ocak 2013].

T.C. Dışişleri Bakanlığı, “No: 286, 12 Aralık 2012, AB Genel İşler Konseyi Sonuçları Hk.”, http://www.mfa. gov.tr/no_-286_-12-aralik-2012_-ab-genel-isler-konseyi-sonuclari-hk_.tr.mfa [Erşim tarihi 22 Aralık 2012].

“Vizede ‘Geri Kabul Anlaşması’na bilim dünyasından itiraz”, 22 Haziran 2012, http://www.ortadogugazetesi. net/haber.php?id=24407, [Erişim tarihi 28 Aralık 2013].

“Vize muafiyeti tuzak mı?”, Milliyet, 22 Haziran 2012, http://gundem.milliyet.com.tr/vize-muafiyeti-tuzakmi-/gundem/gundemdetay/22.06.2012/1557409/default.htm, [Erişim tarihi 24 Ocak 2013].

"Vize muafiyeti müjdesi’ne Bakan Bağıș’tan veto!", 25 Aralık 2012, http://haberpan.com/haber/vizemuafiyeti-mujdesine-bakan-bagistan-veto [Erişim tarihi 12 Ocak 2012].

Zeyrek, D., "Vizesiz AB 2015’te”, Radikal, 22 Haziran 2012, radikal.com.tr, [Erişim tarihi 18 Ocak 2013]. 


\section{Sonsöz}

Bu makalenin basım sürecinde Türkiye ile Avrupa Birliği arasında vize muafiyeti ve ABGKA konusunda yaşanan önemli gelişmeler bu sonsözü ekleme gereğini doğurmuştur. 2011'de patlak veren Suriye iç savaşı milyonlarca Suriyeli'yi yurdundan etmiş ve Türkiye başta olmak üzere komşu ülkelere kaçmalarına neden olmuştur. Dahası Suriyeli kaçak göçmenler nedeniyle bazı Avrupa Birliği üye ülkeleri Schengen Anlaşması'nı askıya almıştır. İki milyondan fazla savaştan kaçan Suriyeli sayısıyla en fazla sı̆̆ınmacıya ev sahipliği yapan Türkiye ile II. Dünya Savaşından beridir ilk defa bu kadar büyük bir göçmen akınıyla karşılaşan Avrupa Birliği arasında 29 Kasım 2015 tarihinde bir "mülteci” zirvesi düzenlenmiştir. Bu zirvenin en önemli pazarlık noktalarından biri ise Geri Kabul Anlaşması ve vize serbestisi olmuştur.

Bu zirvede Suriyeli sığınmacıların Türkiyede yaşam koşullarının iyileştirilmesi için başlangıçta üç milyar Avroluk bir mali yardım paketi sunulması karara bağlanmıştır. Diğer bir konu adaylık sürecinin tekrar canlandırılması olup, bunun ilk somut sonucu 14 Aralık 2015'te bir müzakere faslının daha açılması olmuştur. Ancak Türkiye-AB zirvesinin en kilit konusu ABGKA’nın Haziran 2016’ya kadar tam olarak uygulamaya konulması karşılığında Ekim 2016 itibari ile Türk vatandaşlarına Schengen alanına kısa süreli ziyaretler için vize muafiyeti tanınması olmuştur. Zira Suriye’den gelen düzensiz göçün boyutları Avrupa Birliği için bir mülteci krizine dönüşmüş olup, Türkiye ile imzaladığı ABGKA’nın hayata geçmesini kritik önemde bir konu olarak değerlendirmektedir.

Bu zirveyi sonuçları itibari ile yeni bir gelişme olarak değerlendirmek aslında zordur. Bunun, diğerlerinin yanı sıra, öne çıkan üç nedeni vardır. Vize serbestisinin tanınması için 2013'te Türkiye’nin önüne "yol haritası" ile konulan yetmişten fazla koşulda herhangi bir değişiklik, azalma, hafifletme ya da erteleme söz konusu değildir. Aksine bir süredir Türkiye-AB ilişkilerindeki duraksamanın ve Suriye krizinin bir sonucu olarak yapması gereken reformlarda pek ilerleme kaydetmeyen Türkiye’nin sorumluluklarını, ilk planlanandan da önce, yaklaşık yedi ay içerisinde yerine getirmesi beklenmektedir. İkincisi, bu zaman kadar Avrupa Komisyonu tarafindan sadece bir kere "yol haritası" ile ilgili bir İlerleme Raporu (20.10.2014) hazırlanmış; bu raporda Türkiye'nin yerine getirmesi gereken koşullardan çok az bir kısmını tamamlayabildiği, birçok konuda kısmi ve küçük reformlarla yetinildiği, otuza yakın koşulda ise hiç ilerleme olmadığı tespit edilmiştir. 2015 sonunda sunulması gereken ikinci raporun Mart 2016’ya ertelenmesinin altında yatan nedenlerden biri, son rapordan bu yana fazla ilerleme kaydedilemediği için yeni dönemdeki ivmeyle pozitif bir rapora imza atma isteği olabilir. Son olarak, Türkiye tüm yükümlülüklerini yerine getirse bile vize serbestliği için hem Konsey’in hem Avrupa Parlamentosu'nun bu konuda oylama yapacağı unutulmamalıdır. Avrupa Birliği açısından aslında tam da Türkiye’ye karşı "güven eksikliği" sorununun tekrar gündeme gelmesi söz konusu olabilir. Aşırı sağ partilerin tekrar yükselişte olduğu, kamuoyunda göçmen korkusunun terörizm tehdidi ile birleştiği bir konjonktür, böyle bir vize serbestisini desteklemekten oldukça uzak görünmektedir.

“Tarihi” zirveden sonra, yukarıda kısaca ifade edilen "güvensizlik sarmalı" tekrar dönmeye 
başlamış görünmektedir. AB'deki çeşitli aktörler, varılan anlaşmanın etkisinin sanıldığı şekilde olmadığı, örneğin Türkiye’nin üyeliğini otomatik olarak açmadığı, verilecek finansal yardımın kontrollü bir şekilde ve parçalar halinde verileceği gibi hususlarda kendi kamuoylarını teskin etmeye çalışırken; Türkiye’de zirve "yeni bir başlangıç", AB’ye adaylık sürecinde "tarihi bir gün” olarak sunulmuştur. Vizelerin kaldırılması ise sanki koşulsuz olarak nihai bir tarihe, Ekim 2016’ya bağlanmış izlenimi yaratılmıştır. Öte yandan, Türkiye'nin söz verilen tarihe kadar yükümlülüklerini yerine getirmesi halinde Avrupa Birliği üzerinde bir siyasi baskı oluşacağı, ayrıca Anlaşma’nın uygulanmasının getirdiği faydalardan vazgeçmek istemeyen AB'nin nihayetinde vize serbestisi sözünü tutacağı da ön görülebilir. Ancak, böyle bir durumda bile, gerek fayda-maliyet analizleri ve yükün adaletli paylaşımı açısından Anlaşma’nın Türkiye’nin aleyhine bir görüntü arz ediyor olmasını, gerekse güvensizlik sarmalından çıkışın mülteci hakları açısından sorunlu olan bir anlaşmanın uygulamaya konulmasına bağlanmış olmasını birçok açıdan olumlu değerlendirmek zordur. 